\title{
The effectiveness of the parliamentary front on sport in the Brazilian National Congress between the World Cup and the Olympic Games $^{3}$
}

\section{Introduction}

The aim of this article is to analyse the effectiveness of the Parliamentary Front on Sport in the Brazilian National Congress (Chamber of Deputies and Senate - equal to Lower and Upper Houses). Parliamentary fronts are informal and supra party institutions created by the member of the congress with the objective of articulating themselves politically to act as a group capable to exert political clout in the legislative decision-making process with purpose to promote federal legislation concerning a specific topic (Chamber of Deputies 2005a; Sena, 2007: p.2). The configuration of this type of institution is a network where the relationships among the members are based upon several types of exchanges, such as access and trading of information, the negotiation of appointments, budget resources, prestige, votes, etc. in order to achieve a common network goal, related to specific legislation (Gould 1989; Burt, 1995; Ansell et al., 2016).

\footnotetext{
1 Departamento de Educação Física e Esporte, Instituto Federal de Educação, Ciência e Tecnologia de Brasília. SGAN Quadra 610 Módulos D, E, F, G - Asa Norte 70830-450, Brasília, DF, Brasil. E-mail: <alessandradiasmendes@gmail.com>

2 Departamento de Ciência Política, Universidade Federal do Paraná. Rua General Carneiro, 460, Ed. Dom Pedro I, $9^{\circ}$ andar, sala 908, 80060-150, Curitiba, PR, Brasil. E-mail: < adriano@ufpr.br >

3 This work was supported by CAPES under Grants n. 99999.002412/2015-02 and 309528/2017-8 PQ-Produtividade em Pesquisa (CNPq).
} 
Sports have been frequently on the agenda of the Brazilian National Congress since 1883 (Mendes e Codato, 2014) and have been featured in Brazil in the previous years as a result of investments concerning the 2014 FIFA World Cup and the 2016 Olympic Games, but also due corruption scandals in the world of Brazilian football ${ }^{4}$.

Despite its registration in 2003, the Parliamentary Front on Sport, which abbreviation is FPE from this name in Brazilian Portuguese, has not yet been a subject of research. Actually, sport is a relatively under-researched area in Brazil (Guimarães, 2009). Exploring the groups that govern sports brings a better understanding about the administrative, legal and political frameworks for sport, which can partially explain the current stage of development of Brazilian sports, and point the way to improve (Mendes, 2013; Mendes e Codato, 2014).

This article aims to conduct a distinct analysis about the effectiveness of FPE during the $54^{\text {th }}$ Legislature (2011-2015) of the Brazilian National Congress. This period has been chosen because involves an interstice between the World Cup and Olympic Games hosted in Brazil, a moment in which we had a lot of financial support in sport in Brazil.

Considering that the aim of FPE is to improve sports legislation and, consequently, its members seek to exert political clout on decision-making spaces of the sport policy, this article seeks to answer: (1) "who are the parliament members that take part of this network?"; (2) "how they articulate themselves politically in a network to exert political clout?"; (3) "what are the determinant factors to be central in this network?; (4) "how these members are effective in exert political clout regarding sports legislation by proposing bills and approving laws?".

4 Such as the Parliamentary Inquiry Commission formed to investigate the contract between the Brazilian Football Confederation and Nike in 2001 (Bombig 2014) and the scandal in 2015 involving the International Football Federation and the Brazilian Football Confederation (Carta Capital 2015; Câmara dos Deputados 2015) 
Based on data on the members of the FPE collected at the Chamber of Deputies and Senate, we will outline and analyse the political clout of this network, employing three sequential procedures. The first is a prosopography analysis of political elites Stone (1971); the second is based on network analysis (Wasserman \& Faust 1994; Ansell et al. 2016) and the third on an analysis of the legislative process of the bills proposed in the sports area.

The main contribution of this article is to analyse the Parliamentary Front on Sport (FPE) for the first time and its effectiveness in exert political clout in the sport policy. Among the few studies on parliamentary fronts $(\mathrm{PF})$, we have the comprehensive analysis of the theoretical and methodological nature of them made by Silva \& Araújo (2019) that sought to identify the scope and strategies adopted by the PF, and established a classification for all PF from the 52nd to 55th Legislature in Chamber of Deputies. This classification allowed the comparison and expansion of the scope of initiatives individually achieved through specific case studies. Although broad, such classification did not cover specific themes such as sport, which they just mentioned and it was not considered on their study.

The article is structured into four sections. The first section is about the FPE in the Brazilian Congress, in order to explain what the parliamentary fronts and benches are in terms of political action in the congress. Next, we detail the research methods adopted in this research. Thirdly, we will analyse the network, its members, and the bills proposed on sports. Finally, we conclude the implications of our main findings.

\section{The Parliamentary Front on Sport - Frente Parlamentar Mista do Esporte (FPE)}

The Parliamentary Front on Sport (FPE as abbreviation from its Brazilian name Frente Parlamentar Mista do Esporte) was registered even before the official requirement to registry Parliamentary Fronts in the congress, established by Act n. 69/2005 of the Chamber of Deputies (Câmara dos Deputados, 2005a; Câmara dos Deputados, 2005b). The approval of this Act was controversial, because when 
determining that the Parliamentary Front should have $1 / 3$ of the members of the Congress to be registered, this action allowed the central group of a parliamentary front (known as bench) to be hidden among the other members.

Therefore, the first record of the FPE was establish on 2 December 2013 during the $52^{\text {nd }}$ Legislature, under the presidency of federal deputy Ivan Ranzolin (PPB-SC). The record persisted on 5 May 2006, during the $53^{\text {rd }}$ Legislature under the presidency of federal deputy Manuela D'Ávila (PCdoB/RS). The FPE was relaunched on 17 August 2011, under the presidency of the former athlete of box and federal deputy Acelino Popó (PRB/BA) with deputy D'Ávila as vice-president, at that time, it comprised more than 200 deputies and 7 senators. In $54^{\text {th }}$ Legislature the FPE was registered on 2 September 2013 under the same direction board and comprised 301 deputies and 25 senators, however at the end of 2014 it had 198 deputies and 8 senators.

This front was established with the objective of producing policies which seek to support athletes and sports. There is no record of the current activities of the FPE since the entity's website is offline, despite the fact it was once again registered in the $55^{\text {th }}$ Legislature (2015-2019). Although registry in the Chamber of Deputies requires the listing of its members and statute, only the listing of members is available.

The FPE is frequently referred to as the "Bancada da Bola" [The Bench of the Ball] what is a misunderstanding. The Bench of the Ball emerged in 1991 during the processing of the first law that regulate football in Brazil, the Law n. 8672 (6 July 1993) , which transformed football clubs into private companies and regulated labour relations between players and clubs. This Bench emerged at that time because it involves deputies and senators whose campaigns were financed by football clubs, by the Brazilian Football Confederation itself and its sponsors in exchange for bills and laws which favoured football clubs and the Brazilian Football Confederation (CBF) in Congress,

5 This law was dubbed the "Zico Law" in honor to Arthur Antunes Coimbra, former football player. 
as shown by investigations of the Parliamentary Committee of Inquiry installed to scrutinize the contract between CBF with Nike (Câmara dos Deputados 2001; Leão Júnior, 2004; Bueno, 2008; Veronez, 2005; Hirata, 2011). The political clout of the Bench of the Ball is so strong that the Parliamentary Committee of Inquiry was archived without a report in 2001 (Bombig, 2014). This bargaining characterized by a relationship between campaign financing and favorable bills and laws in Congress has also been identified by Machado (2013) regarding the Rural Bench.

In 2001, during this Parliamentary Committee of Inquiry, the Deputy Romário (PSB/RJ) ${ }^{6}$ accused some of this members to disturb the investigations by own interest, asserting that they are corrupted deputies from the Bench of the Ball. Romário de Souza Faria is a former football star and World Cup winner with the Brazilian team in 1994. He was elected deputed for the 54th Legislature (2011-2015) and reelected as senator in the 55th Legislature (20152018) have been his campaign financed by the same companies he accused before to finance the Bench of the Ball (Perrone 2013), being AMBEV one of them.

In addition, the few references we found about the Bench of the Ball indicate that it is comprised by few congressmen, somewhere between 7 and 18 members (Bueno, 2008:248; Cruz, 2014; Guimarães, 2014; Rebello \& Cruz, 2014; Silva, 2013) and thus cannot be conflated with the FPE, which currently is formed by 206 members. However, it might be diluted inside the FPE.

In this way, a Parliamentary Front is not the same as a Bench. Both are defined as a group of congressmen that come together around a certain issue to act "en bloc" to exert political clout. Both are supra party and informal institutions, as they gather members of Congress from different parties and they are not registered formally in the regiment of the Congress. However, unlike a parliamentary

6 Romário de Souza Faria is a former football star and World Cup winner with the Brazilian team in 1994. He was elected deputy in the 54th Legislature (2011-2015) and reelected as senator in the 55th Legislature (2015-2018) having his campaign financed by the same companies he accused before to finance the Bench of the Ball (Perrone 2013), being AMBEV one of them. 
front, a bench lacks any registration in the National Congress, and it is composed for a nonspecific number of members. The most likely hypothesis is that the Bench of the Ball is the operative core of the FPE.

\section{Methodology}

The purpose of a Parliamentary Front is to exert political influence on a specific political issue. As such, all Parliamentary Fronts constitute a network of relevant actors to this end. Thus, characterizing the Parliamentary Front on Sport (FPE) as a network involves not only analysing their members, but also how these members relate to the FPE and each other, including their distribution in different decision-making bodies related to sport in Congress and how they act to influence sports policy.

The research was conducted based on data around the members of the FPE provided by the Chamber of Deputies and the Senate. Next, there is the explanation of each part of the method used followed by the Table 1 which summarized the Research Design.

a) Prosopography: the socio-political profile of the members of the FPE

For a general overview of the members forming this network we begin with prosopography data relative to the profiles of all members, including deputies $(n=198)$ and senators $(n=8)$. In this profile we considered: age, sex, party, ideological bloc, geographical region represented, level of schooling and field of specialization, profession, political ideology, party, positions in the party, previous electoral positions, number of legislatures, appointments in commissions (decision making instances - specifically in commissions related to sports and key commissions at the Congress), if there is a exclusive participation in FPE or whether if they participate in more parliamentary fronts, and associative activities to institutions sports-related outside de Congress.

This characterization is important in order to highlight the participation of senators in this particular front, as mixed parliamentary fronts, i.e. fronts with members from both houses, are uncommon. 
In addition, this characterization allows for the exploration of a series of factors that allow us to assess the network's potential to exert political clout on sport policy.

b) Network Analysis

Since the FPE is a network seeking to exert political clout, the evaluation of this network's structure, based on the relationship between the deputies of the FPE and the decision-making spaces (commissions) they occupy in the National Congress, is useful in evaluating its effectiveness (Gould 1989; Ansell et al. 2016).

Network analysis arise as a new theory as result of concern amongst sociologists and anthropologists around the connections between individuals and how these ties create order and meaning within social life. Greater attention to this form of analysis began in the 1970s and introduced new elements through which to understand the dynamics of social structure, offering method and theory (Tichy, Tushman \& Fombrun, 2009). According to network theory, there are multiple possible relationships among actors of a network. Hence, analysing the structural and relational position of actors provides a way to understand both a network's functioning and the strategies adopted by actors within to achieve their goals (Masquietto, Sarcomano Neto \& Giuliani, 2011; Mesquita et al., 2008; Ribeiro \& Corrêa, 2013; Tomaél \& Marteleto, 2006; Wolf, 2008; Zurbriggen, 2006).

Wasserman \& Faust (1994) point out "density" and "centrality" as key structural measurements. The density of a network concerns the number of links among actors; whereas centrality refers to the number of links each actor creates in relation to others, in comparison to total number of possible links. As such, centrality is extracted from density, as it corresponds to the relative position of an actor based on the greater density of relations.

The structure of FPE network, formed by the commissions occupied by its members, was analysed with the use of Pajek software, version 4.01, which provided us with measurements of centrality for each congressman. We calculated three measures of centrality: centrality degree, closeness centrality and betweenness 
centrality. The centrality degree represents the number of actors a particular actor (actor $i$, for example) is connected to in relation to the total number of actors. Closeness centrality is related to the proximity of the relationship among actors. Put simply, if actor $i$ is directly connected to another actor, $j$, the distance between $i$ and $j$ is 1 . If $i$ and $j$ are not connected directly but are connected by a third actor, $k$, there is a path from $i$ to $j$ that goes through $k$; the distance therefore between $i$ and $j$ is two, in other words, two connections are necessary to link $i$ and $j$. Closeness centrality adds all of the "shortest distances" between $i$ and all other actors and weighs them against each other. Betweenness centrality takes into account whether a particular actor "connects" other actors, when betweenness centrality is high, it means that a particular actor acts as a "bridge" between many other actors.

Each node in the network are one actor, which size vary according his respective grade of centrality. The vertex of the network are the commissions and their size vary depending on the number of members. The criteria to create the network based on participation in commissions has been chosen in order to identify the relationships between the members in the congress, specifically how the seek to occupied relevant decision-making spheres in sports legislation. We know that there are informal relations that this analysis is incapable of capturing, also this participation in commissions occurs with institutional restrictions, given that the seats in a commission are proportional to each party's representation, which also dictates which deputy will represent it. However, these compositions can be negotiated among parties, and these appointments are quite dynamic, during the $54^{\text {th }}$ Legislature they ranged between 3 and 88 amongst FPE's members, not to mention cases of members who entered and left a commission multiple time.

In a separate analysis, we divided the network to create a sub-network and analysed only the members of the FPE network that participated in commissions related to sports in the National Congress during the $54^{\text {th }}$ Legislature - bimodal sub-network in which there 
are the vertices are FPE's members and the sports commissions in which they participate.

c) Testing the hypothesis - the main factors to be central within FPE network

The prosopography data was inputted in SPSS software (version 22) and grouped into four proxy variables (factors): political expertise, party credibility, specialization in sports and membership (participation in sports-related institutions outside the National Congress). These factors were correlated to the measures of centrality (centrality degree; closeness centrality and betweenness centrality) through a binary regression analysis. These factors are better laid out in Table 1.

This regression analysis aimed to test four hypotheses to identify which "factor" dictated a greater centrality for a member within FPE network: (H1) greater political experience (expertise factor), $(\mathrm{H} 2)$ greater party experience (credibility factor), ( $\mathrm{H} 3)$ greater participation in sports commissions, which means more knowledge in sports-related issues (specialization factor) or (H4) greater participation in sport-related institutions outside de congress (membership factor).

However, in this level of analysis we only considered deputies because of two factors: (1) the different internal guidelines of each legislative house prevented a simultaneous, coherent and comparative analysis, and (2) the baseline factor in the structuring of the network was participation in commissions and there exists few mixed commissions (of deputies and senators).

The factors political expertise and party credibility were based on, but not exclusively, the study by Silva Jr. et al. Silva Jr. et al. (2013) attempted to identify the factors that explain the selection of congress members to occupy three different kinds of leadership posts within the Chamber of Deputies - president of the commission, member of the Directing Table and party leader - during the $51^{\text {st }}$ leadership (1999-2003). Recognising that this is a matter of 
agency ${ }^{7}$, due to the many factors involved, the authors started from the assumption that the rationality of congress members would culminate in informal mechanisms of selection, producing a homogeneous profile of leadership that satisfies two factors. The first factor is political expertise, meaning greater technical knowledge of the procedural working of the legislative house, which in turn is a proxy variable formed by the following indicators: antiquity (number of legislatures served in Congress), political experience (elective posts already served), and status (first mandate or re-election). The second factor would be political credibility, referring to a higher level of compromise with party organization in order to achieve collective goals. This proxy variable is formed by the indicators party antiquity (years of filiation to the party in question), party migration post elections (the 1998 elections, in this case), and party experience (posts occupied in the party). Silva Jr. et al (2013) found expertise as the most prominent factor determining who occupies the posts of president of the commission and member of the directing table, while credibility is the factor that most influences the occupation of the post of party leader when compared to median deputies (those not occupying posts of this nature).

In our analysis, we added more indicators to the proxy variable political "expertise": the deputy's parliamentary activity, that is, the appointments in commissions in general, with an specific attention to appointments in four key commissions in the Brazilian National Congress (Directing Table; Constitution and Justice Commission;

7 In the field of Political Science and Economics, the term "agency" refers to "agent-principal problem" or "agency/dilemma problem", which means the conflict of interest inherent to any relationship in which information is asymmetrical and incomplete. In other words, when one expects one party (the agent) to act in the best interest of the party (the principal), there is the problem that the agent - who supposedly makes decisions in the interests of the principal - is naturally motivated by self-interest and the interests of the agent are different than those of the principal (Ross 1973). Several mechanisms can be used in the attempt to align these interests, such as payments with commissions, profit sharing, performance evaluations or fear of dismissal. The "principal-agent" problem is found in most employer-employee relations as when, for example shareholders hire top executives. This problem was identified by Political Science in its observations of the problems inherent to the delegation of legislative authority in bureaucratic agencies. Another example is the enforcement of legislation, which is open to bureaucratic interpretation, which creates opportunities and incentives for the bureaucrat as an agent to deviate from the preferences and intentions of legislators. 
Ethics and Parliamentary Decorum Commission; and the Parliamentary Attorney's Office). On the other hand, when it comes to the proxy variable "credibility", instead of considering party antiquity and party migration after the election, we considered party fidelity during the length of each FPE member's political career.

In addition, we create two more factors specifically related to our object of analysis. The proxy variable "specialization" in sports-related issues was formed by 3 indicators: if there is education in the area of health sciences, that includes sports area; if there is an exclusive participation in FPE, since a congress member can associate himself as many parliamentary fronts he wish; and appointments in commissions linked to sports in Congress. The proxy variable "membership" in institutions sports-related outside the Congress, seeks to verify a relationship with the issue of sports beyond the scope of actions in Congress.

Thus we expect that the network will be composed by professional politicians, with expertise and credibility, that possess specialization and a connection to the issue of sports, in line with the findings of Wolf's study which concluded that deputies with a greater number of connections resulted in greater centrality and political clout (Wolf 2008: p.38), in our case, political clout within sports legislation. 
Table 1 - Research design

\begin{tabular}{|c|c|c|c|c|c|}
\hline \multicolumn{6}{|c|}{$\begin{array}{l}\text { Composition of the Population ( } n=198 \text { deputies and } 8 \text { senators) } \\
\text { embers of the FPE during the } 54 \text { th Legislature of the Brazilian National Congress }(n=206)\end{array}$} \\
\hline \multicolumn{6}{|c|}{ Characteristics: age, sex, party, ideological bloc, region, education, profession, political ideology and party } \\
\hline \multicolumn{6}{|c|}{$\begin{array}{l}\text { Mixed Methods Analysis: Prosopography and Network Analysis } \\
\text { s in the FPE during the 54th Legislature of the Brazilian National Congress }(n=198)\end{array}$} \\
\hline $\begin{array}{c}\text { Unit of } \\
\text { observation }\end{array}$ & \multicolumn{2}{|c|}{ Technique } & $\begin{array}{l}\text { Proxy } \\
\text { Variable }\end{array}$ & Indicators & Measures \\
\hline \multirow{4}{*}{$\begin{array}{c}\text { Individuals } \\
\text { (deputies and } \\
\text { senators }>n=206 \text { ) }\end{array}$} & \multirow{4}{*}{\multicolumn{2}{|c|}{$\begin{array}{l}\text { Profile Analysis } \\
\text { (Prosopography) }\end{array}$}} & 1. Expertise & $\begin{array}{l}\text { A. Antiquity in Congress } \\
\text { B. Political Experience } \\
\text { C. Status of candidate } \\
\text { D. Parliamentary Activity8 } \\
\text { E.Presence in key com- } \\
\text { missions of Congress }\end{array}$ & $\begin{array}{l}\text { a) № of legislatures in Congress } \\
\text { b) № of elective positions } \\
\text { previously occupied } \\
\text { c) First term or re-elected } \\
\text { d) № of appointments } \\
\text { in commissions } \\
\text { e) Mandates in } 4 \text { key commissions } \\
\text { in the Chamber of Deputies: } \\
\text { Board of Directors; Commission of } \\
\text { Constitution and Justice; Ethics and } \\
\text { Parliamentary Decorum Commission; } \\
\text { and Parliamentary Attorney General }\end{array}$ \\
\hline & & & 2. Credibility & $\begin{array}{l}\text { F. Party rooting } \\
\text { G. Party experience }\end{array}$ & $\begin{array}{l}\text { f) Party rooting of party migration } \\
\text { g) Posts in party executive board }\end{array}$ \\
\hline & & & $\begin{array}{l}\text { 3. Specia- } \\
\text { lization }\end{array}$ & $\begin{array}{l}\text { H. Level and area of schooling } \\
\text { I. Exclusive participation in FPE } \\
\text { J. Activity in commissions } \\
\text { related to sports }\end{array}$ & $\begin{array}{l}\text { h) Some level of schooling (a } \\
\text { diploma) in the level of health } \\
\text { (which encompasses sports) } \\
\text { i) Exclusive participation in } \\
\text { FPE or also in other fronts } \\
\text { j) Presence in commissions } \\
\text { related to sports }\end{array}$ \\
\hline & & & 4. Membership & $\begin{array}{l}\text { K. Union activity, sectoral or asso- } \\
\text { ciative activities related to sport }\end{array}$ & $\begin{array}{l}\text { External relationship to sport (such } \\
\text { as having been the president of } \\
\text { a sports club or an ex-athlete) }\end{array}$ \\
\hline $\begin{array}{l}\text { Group } \\
(n=206)\end{array}$ & \multicolumn{2}{|c|}{ Network Analysis } & Centrality & $\begin{array}{l}\text { Actors pointed out as } \\
\text { central in the network }\end{array}$ & $\begin{array}{l}\text { Degree of centrality } \\
\text { Degree of closeness } \\
\text { Betweenness }\end{array}$ \\
\hline \multicolumn{6}{|c|}{ Hypothesis Test (Deputies $>n=198$ ) } \\
\hline \multicolumn{2}{|c|}{$\begin{array}{l}\text { (H1) FPE's members with } \\
\text { greater political expertise } \\
\text { display more centrality }\end{array}$} & \multicolumn{2}{|c|}{$\begin{array}{l}\text { (H2) FPE's members with } \\
\text { greater party experience } \\
\text { (credibility) are more } \\
\text { central in the network. }\end{array}$} & $\begin{array}{l}\text { (H3) FPE's members more active } \\
\text { in sports-related commissions and } \\
\text { therefore with greater specialization } \\
\text { are more central in the network }\end{array}$ & $\begin{array}{l}\text { (H4) FPE's members displaying } \\
\text { membership regarding sports } \\
\text { (outside congress) have more } \\
\text { centrality in the network }\end{array}$ \\
\hline
\end{tabular}

8 The Senate did not make this specific set of data available with regard to senators, meaning that it is impossible to know the number of commissions they participated in during the 54th Legislature. They only provided the committees in which they were present in 2014, when the data was collected. Be that as it may, the data concerning the 8 senators of the FPE are presented just to provide a picture of the whole, given that they were not considered in the hypothesis test. 


\section{d) Measuring political influence}

Lopes (2013) is currently the only author, which did some kind of evaluation about the political clout of a parliamentary front, namely the Evangelical Parliamentary Front, through bills proposed that became laws. We made a little more than that, we measured political clout, termed Legislative Efficacy through the analysis of number of bills proposed by the FPE and, the number of bills from those which were approved.

\section{Results and Discussion}

The results presented in this section refer to: (a) the profile of members of congress who compose the FPE; (b) the network structure they formed for decision-making in the National Congress (NC); (c) the testing of hypotheses between factors related to the political profile of these members and their respective positions in this network; and (d) the preliminary analysis of the FPE's political influence in sports legislations produced during the specified time period. In the results we consider all members, with the exception of hypotheses' tests, which involve the prosopographical variables and only the lower house members' (deputies) within the network, as explained in the methodology.

a) Prosopography: the socio-political profile of the members of the FPE

Out of 206 FPE members, most are men (93\%), belong to the liberal professions $(61 \%)$ and have a university degree in humanities $(32 \%)$ or law $(30 \%)$. They average 54 years of age, ranging from 22 years old [Alexandre Leite (DEM/SP $\left.{ }^{9}\right)$, Hugo Mota (PMDB/ $\mathrm{PB})$ and Wilson Filho (PTB/PB)] to 91 [Camilo Cola (PMDB/ES)]. Most members fall between 46 to 55 years old $(n=71)$ and 56 to 65 $(n=67)$; only 42 were below the age of 45 .

The majority of FPE members hail from the Brazilian regions of Northeast (34\%) and the Southeast (30\%), followed by the South (16\%), North (13\%), and Central-West (7\%). This is interesting, as

9 DEM, PMDB and PTB are political parties; SP, PB and ES are acronyms of the Brazilian states. 
it does not correspond to the proportions of Congress as a whole. The North-eastern and South-eastern region have very disparate levels of sports infrastructure, number of sports clubs, and state government investment (DaCosta, 2006a, 2006b). The prevalence of the Northeast may indicate a shift in this scenario and provide these regions with better sports infrastructure. Similarly to the Parliamentary Agricultural and Livestock Front, the member distributions corresponds to the regions with the most agricultural production - the South, Southeast, and Center-West (Intini \& Fernandes, 2012).

Another important issue in describing this group is the remarkable distribution of its 206 members across 19 different parties. During the $54^{\text {th }}$ Legislature the Senate was composed of 16 different political parties and the House had 23. The significance of the FPE scattering throughout 19 parties is amplified when compared to the Frente Parlamentar Agropecuária (FPA), as this parliamentary front was considered to have the most political leverage in Congress (Vigna 2001; Vigna 2007; Sena 2007; Intini \& Fernandes 2012; Machado 2013) and during the 54th Legislature it contained 17 parties and 202 members (191 lower house members and 11 senators) (Intini \& Fernandes 2012).

These 19 parties were separated into ideological blocs (centre, left, right) according to Codato et al. (2015). Within the FPE the right has the biggest bloc (44\%), followed by the left (35\%). Considering that the Ministry of Sport is, since its creation, a beachhead of leftist political parties like the PT or $\mathrm{PCdoB}^{10}$, the fact that the FPE is composed mostly of right-wing parties is surprising. However, this proportion is similar to the proportions within 54th Legislature as a whole. And it is also in accordance with Coradini's findings (2010: p.249) regarding the 52nd Legislature (2002-2006), which emphasise the predominance of right-wing parties in spheres with a strong economic character, sports included.

A summary of the FPE member's profiles is on the Table 2 below.

10 Ministers of Sport and respective parties: Agnelo Queiroz - PT (2003-2006); Orlando Silva - PcdoB (2006-2011); Aldo Rebelo - PCdoB (2011-2015). 
Table 2 - Composition of FPE members

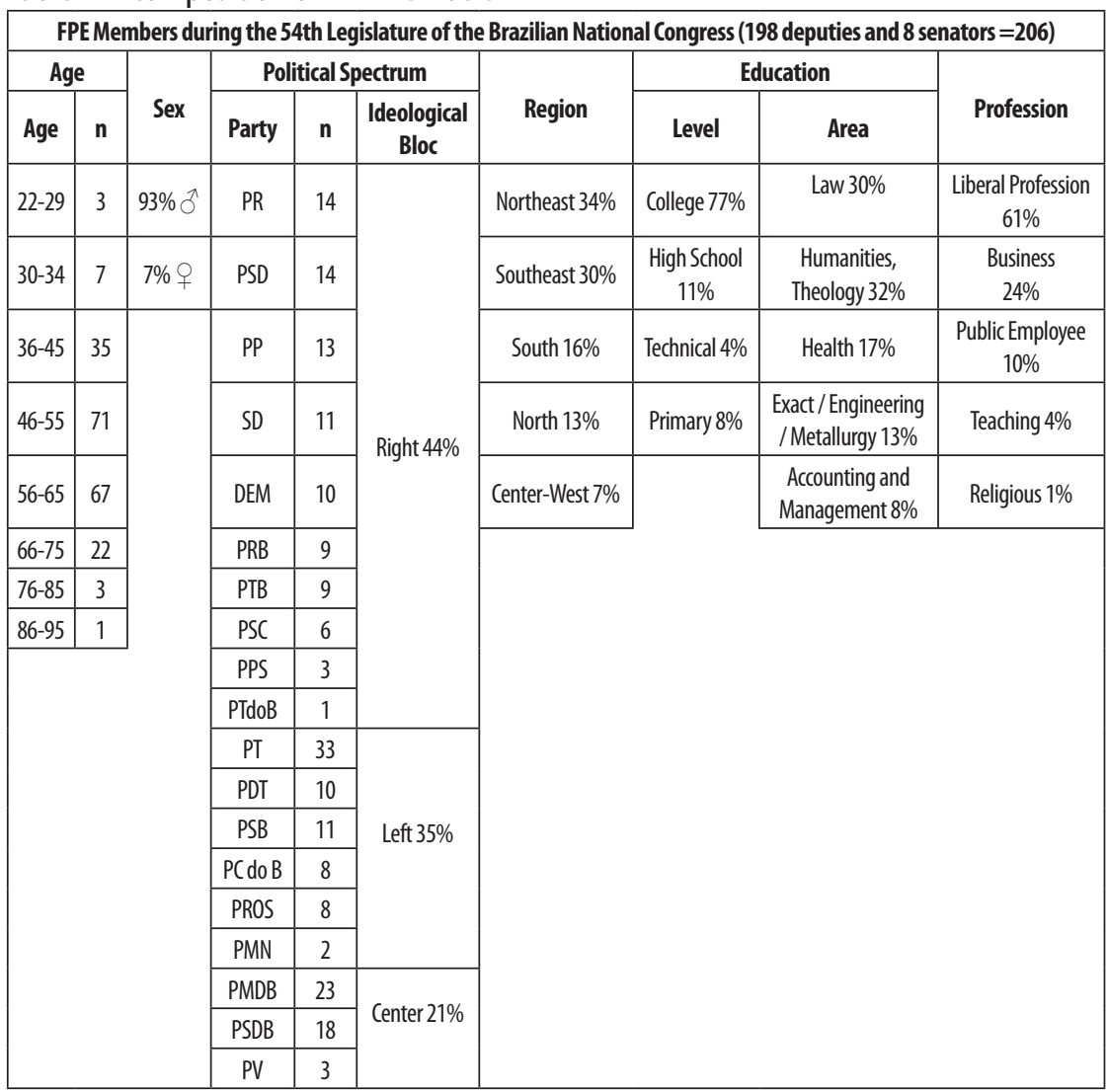

Source: Author, based on Congress data according to classification by Codato et al. (2015).

b) Network Analysis of Parliamentary Sports Front

To analyse the network, we created a database using Pajek 4.01 in which the nodes and vertexes were composed by members and the decision-making spheres (commissions) occupied by them in Congress.

In analysing this network, we broke it into a subnetwork with members who were in commissions related to sports (Figure 1). During the 54th legislature, ten commissions related to sports were identified in the Lower House (LH) and the Upper House (UH): 
1. Permanent Commission on Tourism and Sports (CTUR) in the LH;

2. Permanent Commission on Sports (CESPO) in the LH;

3. Special Commission established by Law no 2330/2011, World and Confederations Cups (COPAS) in both houses;

4. Special Commission established by Law no 5201/2013, Supporting Olympic Sports Program (PROFORTE) in the LH;

5. External Commission on the 2014 World Cup and 2016 Olympics Legacy (LEG. COPA JO) in the LH;

6. Permanent Commission on Education, Culture, and Sports in the UH;

7. 2014 World Cup, 2016 Olympics and Paralympics 2016 Temporary Subcommittee (CDRCOOL) in the UH;

8. Permanent Subcommittee on 2014 World Cup and 2016 Olympics Monitoring in the Senate (CMACOPA or CMACOPOLIM) in both houses;

9. Protection of Capoeira Mixed Parliamentary Front (CAPOEIRA) in both houses;

10. Mixed Parliamentary Front for Sports (FPE) in both houses.

Among the 206 FPE members, 66 worked in these 10 sports commissions. When we analysed the importance of this sub-network, we identified 22 members with an increased number of connections (18) with other network members, a result of their joint efforts in other decision-making mechanisms. Of these 22 members, 13 are connected to one or more sports commissions, and 8 of these are more important in this sub-network due to their simultaneous presence in 3,4 , or even 5 other commissions. The members who participate in one or more networks serve as bridges between these different networks or communities, as proposed by Burt (1995). This intermediation determines the degree of influence of these actors regarding the level of cohesion of the FPE within different decision-making spheres in Congress. 
Figure 1 - FPE sub-network: FPE members ( $n=66)$ connected to sport-related commissions during the 54th Legislature.

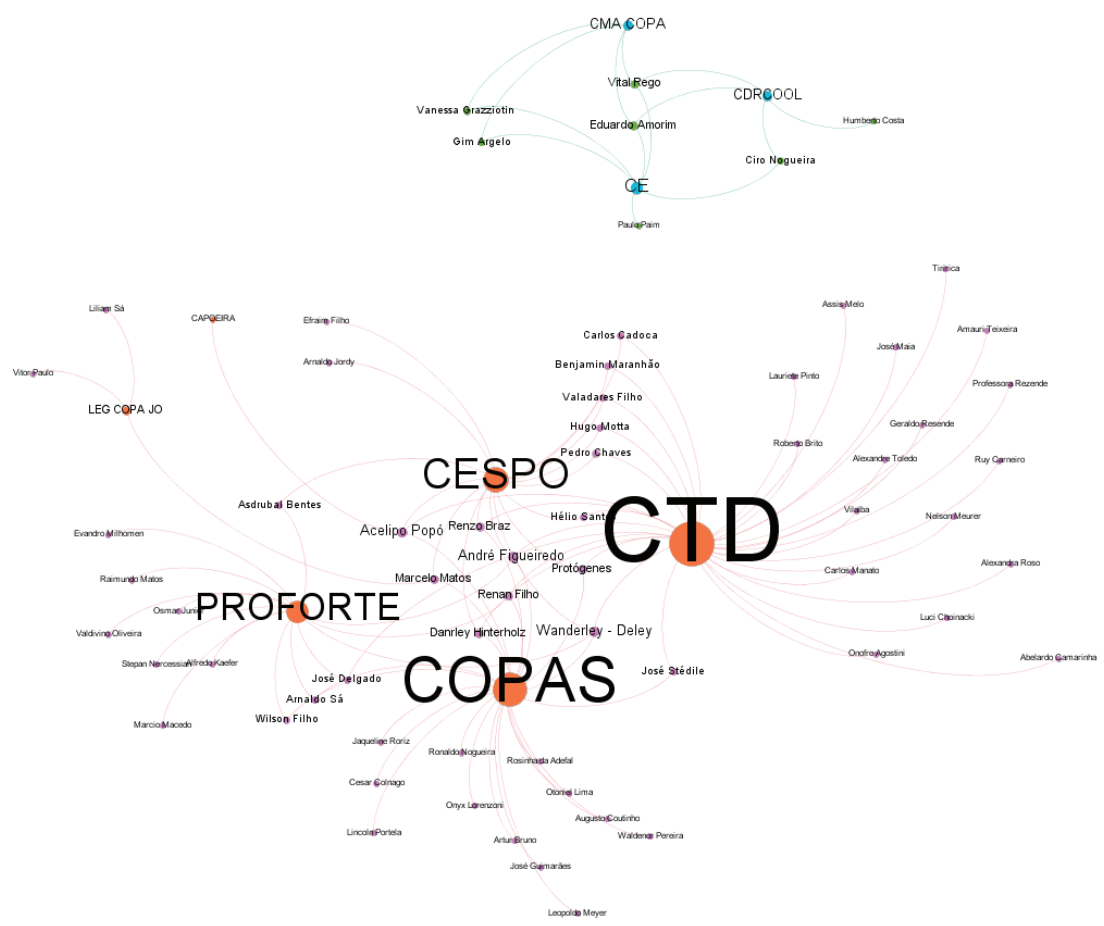

Legend of the figure - The bigger circles in orange and blue (vertexes) represent the 10 commissions related to sports currently functioning in Congress during the 54th Legislature (2011-2015). The size of these bigger circles is proportional to the number of participants in each commission. The smaller circles in purple (nodes) represent the FPE members who were present in these commissions. The size of these smaller circles is proportional to the number of connections each congressman has with other network members.

These issues revive the argument that the FPE is not the same as the Bench of the Ball, since 206 members can not represent very specific interests (Gould 1989; Intini \& Fernandes 2012; Ansell et al. 2016). However, FPE may contain the Bench of the Ball, as its main actors can be the principals of the Bench. Some of the charges against the Bench of the Ball indicate that it is composed by 7 
members (Cruz, 2014; Damato \& Resende, 2014; Guimarães, 2014; Rebello \& Cruz, 2014), almost the same number of congressmen singled out in this subnetwork analysis, obviously it must consider a possible variation or change in the composition of the Bench of the Ball. It is important to highlight that Deputy Renan Filho (PMDB/AL) was the only one founded as a central member within the network that coincided as one of the suitable ones in the accusations on the Bench of the Ball (Rebello \& Cruz 2014).

The 8 main congressmen inside the FPE's subnetwork, all members of the Lower House, were simultaneously present in three or four other commissions related to sports. In three commissions related to sports we have: Danrlei Hinterholz (PSD/RS) (former athlete), Delegado Protógenes (PCdoB/SP), Marcelo Matos (PDT/ $\mathrm{RJ})$, Renzo Braz (PP/MG), Renan Filho (PMDB/AL) and. In four commissions related to sports we have: Acelino Popó (PRB/BA) (a former athlete, four-time world champion of boxing), André Figueiredo (PDT/CE) and Wanderley Deley (PTB/RJ).

Of the main subnetwork members, most were in their first mandate in the 54 ${ }^{\text {th }}$ Legislature: Acelino Popó (PRB/BA), Danrlei Hinterholz (PSD/RS), Delegado Protógenes (PCdoB/SP), Marcelo Matos (PDT/RJ), Renzo Braz (PP/MG) e Renan Filho (PMDB/AL).

Wanderley Deley $(\mathrm{PTB} / \mathrm{RJ})$ was already in his third mandate and André Figueiredo (PDT/CE) in his second. Wanderley Deley (PTB/ RJ) was an athlete and soccer coach in five different sports clubs, a member of five different parties, Municipal Sports Secretary in Volta Redonda/RJ (1997-2002), twice vice-party leader, and had 22 appointments in 14 different commissions in the 54th Legislature. André Figuereido (PDT/CE) does not have any openly declared relationship with sports, never switched parties, and had 8 party positions, 31 appointments in 20 commissions, including the Ethics Council and the Strategic Center of Debate and Planning during the 54th Legislature. Considering these characteristics, we can say that besides being important figures in the FPE's network, Wanderley Deley (PTB/RJ) has political expertise and André Figueiredo (PDT/ $\mathrm{CE})$ has political expertise and credibility within the party.

However, if "political 'expertise", "party 'credibility", "'specialization' in the areas of sports", and "membership' in sports institutions" are four factors that dictated a greater centrality within the network, 
that is something that only a test of hypotheses can prove. Let us see the result in the next section.

c) Testing the hypothesis

Through factorial analysis, based on the prosopographic variables of political careers, we created factors that synthesized the political profiles of the FPE members $(\mathrm{FPE}=206)$, as presented below and summarized in Table 3. However, it is important to note that for this test only the deputies $(n=198)$ were considered as explained in the methodology. First, we present the results of the indicators of each factor.

Table 3 - Results of indicators for each factor of the factorial analysis for FPE members ( $n=206)$. Factors were: "Political Expertise", "Party Credibility", "Specialization in Sports", and "Membership in sports institutions outside Congress".

\begin{tabular}{|c|c|c|c|c|}
\hline $\begin{array}{l}\text { Proxy Variables } \\
\text { (Factors) }\end{array}$ & Indicators & Results & $\mathrm{n}$ & $\%$ \\
\hline \multirow{18}{*}{ 1. Expertise } & \multirow{8}{*}{ A. Congressional Antiquity } & 1 Legislature & 99 & $48 \%$ \\
\hline & & 2 Legislature & 40 & $19 \%$ \\
\hline & & 3 Legislature & 31 & $15 \%$ \\
\hline & & 4 Legislature & 18 & $9 \%$ \\
\hline & & 5 Legislature & 12 & $6 \%$ \\
\hline & & 6 Legislature & 5 & $2 \%$ \\
\hline & & 7 Legislature & 1 & $0.5 \%$ \\
\hline & & Total & 206 & $100 \%$ \\
\hline & \multirow{10}{*}{ B. Political experience } & 1 Elected mandate & 33 & $16 \%$ \\
\hline & & 2 Elected mandate & 31 & $15 \%$ \\
\hline & & 3 Elected mandate & 24 & $12 \%$ \\
\hline & & 4Elected mandate & 15 & $7 \%$ \\
\hline & & 5 Elected mandate & 12 & $6 \%$ \\
\hline & & 6 Elected mandate & 8 & $4 \%$ \\
\hline & & Total & 123 & $60 \%$ \\
\hline & & \multicolumn{3}{|c|}{ Of the 123 that had previous elected mandates, those were in: } \\
\hline & & Municipal level & 93 & $76 \%$ \\
\hline & & State level & 74 & $60 \%$ \\
\hline
\end{tabular}




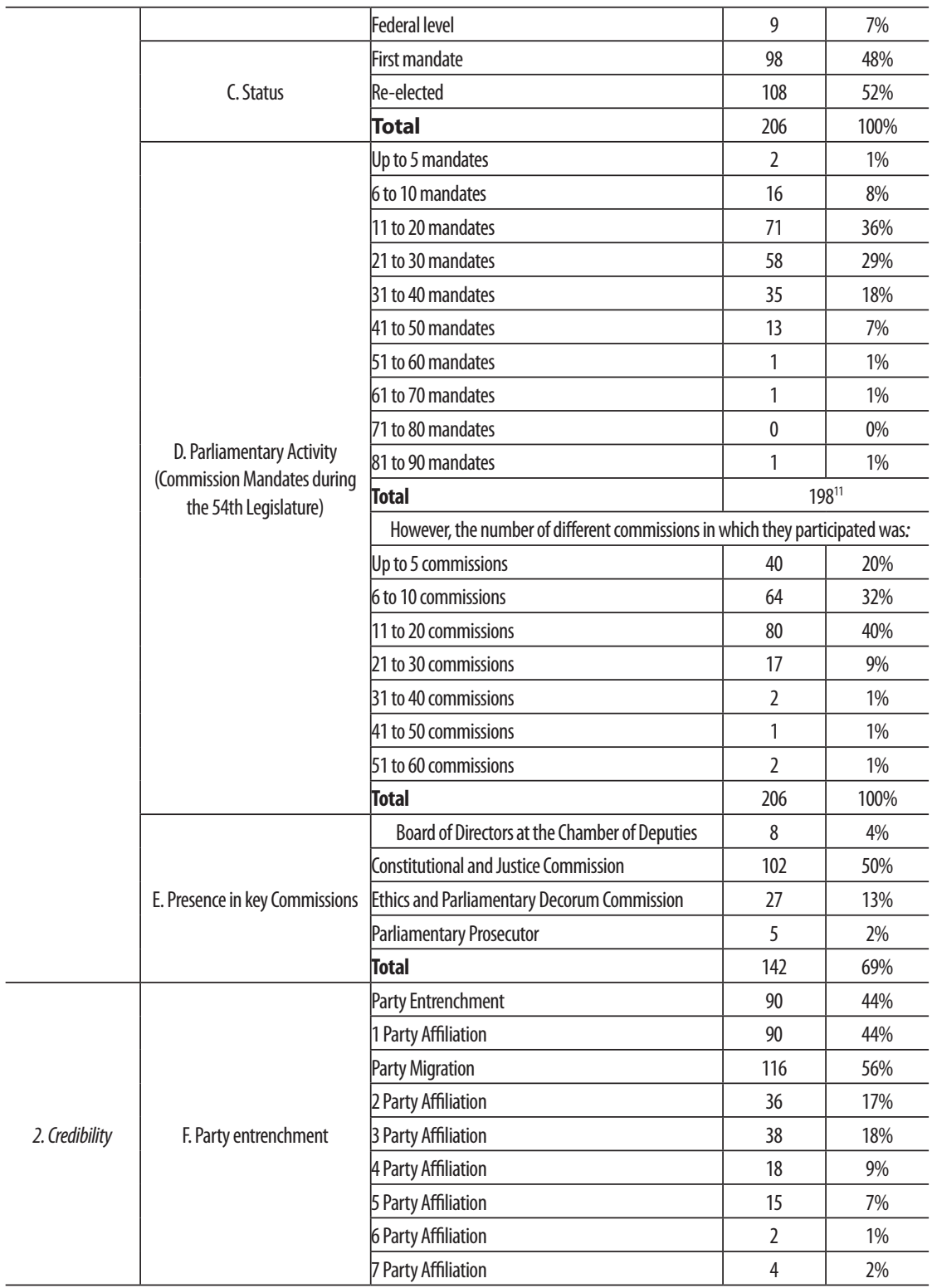

11 This information was not made available by the Upper House (senators). Therefore, it was only possible to present information concerning deputies. It is important to remember, as mentioned in point (d), that often the deputy would enter then exit the same commission multiple times during the legislature. 


\begin{tabular}{|c|c|c|c|c|}
\hline & & 8 Party Affiliation & 2 & $1 \%$ \\
\hline & & 9 Party Affiliation & 1 & $0 \%$ \\
\hline & \multirow{14}{*}{ G. Party experience ${ }^{12}$} & 1 Party Job & 48 & $23 \%$ \\
\hline & & 2 Party Job & 44 & $21 \%$ \\
\hline & & 3 Party Job & 18 & $9 \%$ \\
\hline & & 4 Party Job & 17 & $8 \%$ \\
\hline & & 5 Party Job & 13 & $6 \%$ \\
\hline & & 6 Party Job & 8 & $4 \%$ \\
\hline & & 7 Party Job & 5 & $2 \%$ \\
\hline & & 8 Party Job & 4 & $2 \%$ \\
\hline & & 9 Party Job & 4 & $2 \%$ \\
\hline & & 10 Party Job & 3 & $1 \%$ \\
\hline & & 11 Party Job & 1 & $0 \%$ \\
\hline & & 12 Party Job & 2 & $1 \%$ \\
\hline & & 13 Party Job & 2 & $1 \%$ \\
\hline & & Total & 169 & $82 \%$ \\
\hline \multirow{3}{*}{ 3. Specialization } & H. Education in Health/Medicine & Some level of schooling in any area of health & 28 & $17 \%$ \\
\hline & I. Exclusive Participation in the FPE & $\begin{array}{l}\text { Participates exclusively in the FPE } \\
\text { and not in any others }\end{array}$ & 147 & $71 \%$ \\
\hline & \multicolumn{2}{|c|}{ J. Performance in sports-related commissions during the 54 th Legislature $(2011-2015)^{13}$} & 66 & $32 \%$ \\
\hline 4. Membership & \multicolumn{2}{|c|}{$\begin{array}{l}\text { K. Union activism, representative of class and membership associated with sports; } \\
\text { any other external relation to sports (club president or former athlete for example) }\end{array}$} & 10 & $5 \%$ \\
\hline
\end{tabular}

Regarding the factor political "expertise", for the indicator (a) congressional antiquity, 55\% of congressmen are over their second term. However, there are some over their seventh term [Arnaldo Faria de Sá (PTB/SP)]. With respect to (b) political experience, 60\% have served in another position, be it municipal, state, or federal and as (c) status, 52\% are re-elected for two or more terms.

Concerning (d) parliamentary activity indicator, each FPE member has participated in 12 commissions on average during the 54th Legislature. The variation ranges from at least 3 [Dr. Adilson Soares $(\mathrm{PR} / \mathrm{RJ})$ ] and at most 87 [Arnaldo Faria de Sá (PTB/SP)]. Regarding indicator (d), it is important to point out that (1) only 5 congressmen have been a part of 30 or more commissions; (2) the participation in decision-making spheres was considered as a

12 The party jobs in question involve positions such as: Treasurer; Municipal, State and/or Federal party convention Delegate, Party leader; Party Bloc Leader; (Municipal, State, and/or Federal) Directory President.

13 These commissions are the 10 commissions related to sports during the 54th Legislature (20112015) and represented in Figure 1. 
relevant element for the purposes of this paper, nevertheless such commissions are often created to discuss a specific bill which vary in complexity and duration. Anyhow, the congressmen's performance in a number of simultaneous commissions constitute a data point which may be studied further by future research.

In both houses, the number of commissions is constantly changing, especially the temporary ones, which makes it difficult to compare precisely the number of commissions in which the FPE members participate. The data provided by the Lower House and the Upper House show this imprecision (Table 4), meanwhile FPE members are present in more commissions than the official number disclosed. Despite this, we see a strategic occupation by FPE members in decision-making spheres.

Table 4 - Commissions in which FPE members participate in relation to total commissions of the 54th Legislature (2011-2015), both sets of data were provided by the House and the Senate.

\begin{tabular}{|c|c|c|}
\hline \multirow{10}{*}{ In the House } & FPE Members in & Total Commissions in the House \\
\hline & 22 Permanent Commissions & 22 Permanent Commissions \\
\hline & 209 Special Commissions* & 101 Special Commissions* \\
\hline & 22 External Commissions & 23 External Commissions \\
\hline & $17 \mathrm{CPIs}^{*}$ & $4 \mathrm{CPIs}^{*}$ \\
\hline & 1 Mixed Commissions & 3 Mixed Commissions \\
\hline & 67 Parliamentary Fronts & 210 Parliamentary Fronts \\
\hline & 11 Working Groups & 13Working Groups \\
\hline & 4 Councils* & 1 Council* \\
\hline & 1 Parliamentary Prosecutor & 1 Parliamentary Prosecutor \\
\hline \multirow{9}{*}{ In the Senate } & FPE Members in & Total Commissions in the Senate \\
\hline & 11 Permanent Commissions & 23 Permanent Commissions \\
\hline & 40 Sub commissions & 81 Sub commissions \\
\hline & 8 Mixed Commissions & There is no information available* \\
\hline & 9 Councils & There is no information available * \\
\hline & $18 \mathrm{CPls}$ & 57 CPIs \\
\hline & 20 External and temporary Commissions & 112 External and temporary Commissions \\
\hline & $\begin{array}{l}9 \text { Representative Commissions and others } \\
\text { (such as the Parliamentary Prosecutor) }\end{array}$ & There is no information available * \\
\hline & 38 Veto Commissions & 75 Veto Commissions \\
\hline
\end{tabular}

Source: Author, based on data provided by the House and Senate.

*The inconsistencies between the number of commissions with FPE members and total number of commissions is due to information disclosed by Congress itself. In any case, we kept the information to denote the scattering of the FPE in decision-making spaces in the Congress. 
Regarding (e) presence in key commissions in Congress, focal points of political articulation include:

- $50 \%$ ( $\mathrm{n}=102>95$ deputies and 7 senators) compose the Constitution and Justice Commission (CCJ), a very important commission in both houses;

- $13 \%(\mathrm{n}=27 ; 22$ deputies and 5 senators) of FPE members are in the Ethics Commission in both houses;

- $4 \%$ ( $\mathrm{n}=8>7$ deputies and 1 senator) are members of the Mesa Diretora in both houses, the most important organ of the Brazilian National Congress;

- $2 \%(\mathrm{n}=5 ; 4$ deputies and 1 senator) are members of the Parliamentary Prosecutor's Department in both houses.

The party "credibility" factor of FPE members shows that (f) party entrenchment happened in $44 \%(\mathrm{n}=90)$ of congressmen. Of the $56 \%(n=116)$ that had different party affiliations, they ranged from 2 to 9 parties. Related to $(\mathrm{g})$ party experience, $82 \%(\mathrm{n}=169)$ had some party position.

The "specialization" factor in sports showed that only (h) $17 \%$ $(\mathrm{n}=28)$ had some education at any level of health sciences. Only one, deputy Paulo Rubem Santiago PDT/PE had a degree in Physical Education. Regarding (i) exclusive participation in FPE, only $29 \%$ participated in the FPE alone, $71 \%(n=147)$ participated in other fronts, and $24 \%(\mathrm{n}=50)$ were presidents in them, a relevant fact for their profiles and the network structure related to political clout. Concerning ( $\mathrm{j}$ ) performance in commissions related to sports, $32 \%$ $(\mathrm{n}=66)$ belong to a commission that deals with sports.

As regards to "membership" in sports institutions outside Congress $(\mathrm{k})$, only $5 \%(\mathrm{n}=10)$ of FPE members were involved with sports that did not concern their parliamentary activities, whether as an athlete, member of a coaching team, or manager of a sports club.

After using factorial analysis to group the prosopographic variables as indicators according to these theoretical dimensions (expertise, credibility, specialization, and membership), we employed binary logistic regression to test the following hypotheses: 
$\left(\mathrm{H}_{1}\right)$ FPE members with greater political experience (expertise), and consequently a longer political career including congressional antiquity, greater previously elected terms, higher parliamentary activity in Congress, and greater participation in key commissions; would hold greater "knowledge of the legislative machine" and thus occupy central positions in the network;

$\left(\mathrm{H}_{2}\right)$ FPE members with greater party credibility, that is, party entrenchment and party positions would occupy central positions in the network;

$\left(\mathrm{H}_{3}\right)$ FPE members with more specialized knowledge, due to their education in health sciences, performance in sports commissions, and exclusive participation in the FPE would possess greater specialization in sports and would occupy central positions in the network;

$\left(\mathrm{H}_{4}\right)$ FPE members with memberships in sports institutions outside Congress would occupy central positions in the network.

Regarding the factors and the Centrality Degree in the network, the chi-square test shows that the model (group of independent variables $=$ factors $)$ is significant $(\mathrm{p}<0.01)$ and explains $28 \%$ to $38 \%$ of the dependent variable (centrality), and correctly classifies $76 \%$ of cases. The $\mathrm{H}_{1}(\mathrm{p}<0.01)$ and $\mathrm{H}_{2}(\mathrm{p}<0.01)$ hypotheses were confirmed, that is, expertise and specialization are statistically significantly related to the deputies' Centrality Degree in the FPE network.

Regarding the Closeness Centrality Degree in the network, the chi-square test shows that the model (group of independent variables $=$ factors $)$ is significant $(\mathrm{p}<0.01)$ and explains $29 \%$ to $39 \%$ of the dependent variable (relative degree of closeness), and correctly classifies $74 \%$ of the cases. The $\mathrm{H}_{1}(\mathrm{p}<0.01)$ and $\mathrm{H}_{2}(\mathrm{p}<0.01)$ hypotheses were confirmed, that is, expertise and specializations were statistically significant and are related to the deputies' Degree of Closeness Centrality in the FPE network $(n=198)$.

Regarding the Degree of Betweenness Centrality in the network, the chi-square test shows that the model (group of independent variables $=$ factors $)$ is significant $(\mathrm{p}<0.01)$ and explains $19 \%$ to $26 \%$ 
of the dependent variable (degree of betweenness), and correctly classifies $69 \%$ of the cases. The $\mathrm{H}_{1}(\mathrm{p}<0.01)$ and $\mathrm{H}_{2}(\mathrm{p}<0.01)$ hypotheses were confirmed, that is, expertise and specializations were statistically significant and are related to the deputies' Degree of Betweenness Centrality in the FPE network $(n=198)$.

Regarding party credibility, this was not significant to any of the centrality types, possibly because the FPE is a supra party institution, it means, it is not affiliated to any specific parties. Regarding membership, we expected it to contribute to one of the three types of centrality, but this did not happen, probably because the level of membership in sports institutions outside Congress was low (5\%).

When analysing the hypotheses, it becomes evident that knowledge of the legislative machine (expertise) is the crucial factor, not only for being elected to positions in the Houses, as shown by Silva Jr. et al (2013), but also for centrality in a network such as the Parliamentary Front on Sport. Even though, technical knowledge of the matter at hand (specialization in sports) was also a relevant factor.

d) Measuring political clout - Legislative Efficacy of FPE

The FPE members were responsible for 94 (61.43\%) of 153 bills proposed for legislation in sport. In this period only 30 legislative proposals have become laws, 25 (83.33\%) of which are authored by the Executive Power; from the 9 legislative proposals with participation of the Legislative Power in the 54th Legislature, the FPE members were authors of 5 of these propositions, representing a Legislative Efficacy of 55\%.

When compared with the Evangelical Parliamentary Front, the only Parliamentary Front from which we have some similar data (Lopes 2013), they were effective in approving 3 bills in 2 legislatures, while the Sports' MPs approved 4 bills in 1 legislature.

\section{Conclusion}

Despite the proliferation of parliamentary fronts in Congress, there remains a dearth of studies on their effectiveness in producing legislation (Vogel 2005; Lopes 2013), political clout, political performance, and cohesion (Lopes 2013). We know very little of their true capacity of political articulation in promoting a specific public policy. 
The objective of a parliamentary front is to develop strategies to occupy decision-making spheres and reinforce its power to exert political clout, such group consist of a network of actors. This article sought to analyse the effectiveness of the Brazilian Parliamentary Front on Sport by identifying the structure of the FPE by the analysis of the attributes of its individuals, how they articulate themselves politically, how they position themselves in decision-making spheres in Congress and what is their influence in building sports legislation.

We found that the FPE has a considerable capacity in Congress, especially when we compare our data with the few data available on the Agricultural Parliamentary Front (Intini \& Fernandes, 2012) and on the Evangelical Front (Lopes, 2013).

Taking into account our analysis we found that FPE:

- Is composed by political professionals, with long careers and specialization in sports;

- Has national representation, as it has members of 26 out of 27 federative units;

- And occupies a strategic position in several decision-making spheres, due to the presence of FPE members in different commissions, parties, and internal and external activities related to sports what is determinant for its objective (exert political clout), as pointed also by Cascione (2018);

- As well as their presence in important commissions such as the Board of Directors, the Constitutional and Justice Commissions and Investigative Parliamentary Commissions;

- Also, a strong legislative performance with a legislative effectiveness of $55 \%$;

- Of the 206 members of the FPE, 66 were involved in decision-making spheres related to sports (ten commissions). Of these 66,8 were identified with greatest centrality.

It is possible to conclude that the parliamentary front is spread in the congress, what is determinant for its objective (exert political clout), also the core group that we found shows that there is a much smaller organizational core than might be diluted and hidden in the front, what is also pointed by Cascione (2018). 
This last data shows that there are other explanatory factors for the network's connections that go beyond the specific interest in promoting sports legislation, and these factors can be related to the cooperation between network actors for other interests (Chaserant, 2003; Balestrin \& Vargas, 2004, p.209). This fact demands more research in order to explain this cooperation, especially concerning deputies pointed out by the media as being members of the Bench of the Ball (Bombig, 2001) and the ones listed here as professional politicians, central in the network.

When analysing the hypotheses relating to the determining factors for centrality of an FPE member, we verified that knowledge of the congressional machine and its inner workings and procedures (expertise) and technical knowledge of sports (specialization) proved to be the main factors. This finding lead us not just to a new method to study this kind of institutions but also to a theory about the main factors to be central in such a network. Cervi (2015)

The conclusions of this study were limited by the scarcity of studies on parliamentary fronts to be used as parameters, meanwhile, turns it original and gave us an overview about how they work. Its main contributions were a first analysis of Parliamentary Front on Sport; a mixed method to measure the effectiveness and political clout of a parliamentary front, through its capacity of political articulation utilizing prosopography analysis and network analysis combined, and legislative efficacy as more precise analysis. Also, a theory about the main factor to be central in a political network like this. Our method can be replicated to analyse or make comparisons with other parliamentary fronts or similar forms of coordinated political action.

\section{Acknowledgements}

Esta pesquisa teve apoio financeiro da CAPES com bolsa de doutorado no Brasil e bolsa de doutorado sanduíche no exterior (Processo n. 99999.002412/2015-02). Ainda, esta pesquisa faz parte do projeto "Regimes políticos, hierarquias sociais e profissionalização política dos congressistas brasileiros" pela bolsa de Produtividade em Pesquisa CNPq (Processo n. 309528/2017-8). 
Agradecimentos: ao Prof. Dr. Victor Pelaez e a Thomaz Theodorovicz pelo vislumbre da possibilidade da análise de rede, inicialmente com o Pajek, a qual aprimoramos posteriormente com o uso do Gephi por indicação do Prof Rodrigo Horochoviski. Ao Dom Conricode pelo auxílio na revisão do inglês, e aos servidores da Câmara dos Deputados e Senado Federal pelo auxílio para aquisição dos dados da pesquisa.

\section{References}

ANSELL, C.; BICHIR, R.; ZHOU, S. Who Says Networks, Says Oligarchy? Oligarchies as "Rich Club" Networks. Connections, v. 35, n. 2, p. 20-32, 2016. Disponível em: <http://insna.org/ connections/v35/v35_2_2.html $>$.

BALESTRIN, A.; VARGAS, L. M. A dimensão estratégica das redes horizontais de PMEs: teorizações e evidências. Revista de Administração Contemporânea, v. 8, n. spe, p. 203-227, 2004. Disponível em: <http://www.scielo.br/scielo.php?script=sci_ arttext\&pid =S 1415-65552004000500011\&lng=pt\&tln $\mathrm{g}=\mathrm{pt}>$.

BOMBIG, J. A. CPI da CBF/Nike termina sem relatório. Folha de S.Paulo, 14. jun. 2001. São Paulo. Disponível em: <https://www1. folha.uol.com.br/fsp/esporte/fk1406200137.htm $>$.

BUENO, L. Políticas publicas do esporte no Brasil: razões para o predomínio do alto rendimento, 2008. São Paulo: Fundação Getúlio Vargas. Disponível em: <http://hdl.handle. net $/ 10438 / 2493 \% 0 A>$.

BURT, R.S. Structural holes: the social structure of competition. Cambridge: Harvard University Press, 1995.

CÂMARA DOS DEPUTADOS. Ato da Mesa no 69 de 10/11/2005. Brasília: Diário da Câmara dos Deputados - Suplemento - B, 2005. CÂMARA DOS DEPUTADOS Comissão Parlamentar de Inquérito destinada a apurar a regularidade do contrato celebrado entre a CBF e a Nike. 2001. Available at: http://www2.camara.leg. br/atividade-legislativa/comissoes/comissoes-temporarias/ parlamentar-de-inquerito/51-legislatura/cpinike/informacoessobre-a-cpi. Accessed at: 02 january 2016.

CÂMARA DOS DEPUTADOS, 2005b. Diário da Câmara dos Deputados, Year LX, Issue 197, p.237. 
CASCIONE, S. R. S. Institucionalização e influência das frentes parlamentares no Congresso brasileiro, 2018. Universidade de Brasília. Disponível em: <http://repositorio.unb.br/ bitstream/10482/31903/1/2018_SilvioRicardoSilvaCascione.pdf $>$.

CERVI, E. U. Análise de elites em perspectiva relacional: a operacionalização da análise de redes sociais (ARS). In: R. Perissinotto; A. Codato (Orgs.); Como estudar elites. p.95-118, 2015. Curitiba: Editora UFPR.

CHASERANT, C. Cooperation, contracts and social networks: From a bounded to a procedural rationality approach. Journal of Management and Governance, v. 7, n. 2, p. 163-186, 2003.

CODATO, A.; BOLOGNESI, B.; ROEDER, K. M. A nova direita brasileira: uma análise da dinâmica partidária e eleitoral do campo conservador. In: S. V. e Cruz; A. Kaysel; G. Codas (Orgs.); Direita, volver! : o retorno da direita e o ciclo político brasileiro. p.115143, 2015. São Paulo: Editora Fundação Perseu Abramo.

CORADINI, O. L. Frentes parlamentares, representação de interesses e alinhamentos políticos. Revista de Sociologia e Politica, v. 18, n. 36, p. 241-256, 2010.

CRUZ, J. Quem é quem na "bancada da bola”. Disponível em: $<$ https://josecruz.blogosfera.uol.com.br/2014/05/quem-e-quemna-bancada-da-bola-2/>. .

DACOSTA, L. P. Instalações esportivas por estado. In: L. P. DaCOSTA (Org.); Atlas do Esporte no Brasil. p.5.27-5.29, 2006a. Rio de Janeiro.

DACOSTA, L. P. Clubes esportivos e recreativos. In: L. P. DaCOSTA (Org.); Atlas do Esporte no Brasil. p.6.7-6.12, 2006b. Rio de Janeiro. Em sua maioria, Bancada da Bola é reprovada nas urnas. .O Estado de S. Paulo, 8. out. 2012. São Paulo. Disponível em: <https:// esportes.estadao.com.br/noticias/futebol,em-sua-maioriabancada-da-bola-e-reprovada-nas-urnas,942507>.

Entenda o escândalo da Fifa e da CBF. Carta Capital, 27. maio 2015. São Paulo. Disponível em: <https://www.cartacapital.com.br/ sociedade/entenda-o-escandalo-da-fifa-e-da-cbf-4139/>.

GOULD, R. V. Power and social structure in community elites. Social Forces, v. 68, n. 2, p. 531-552, 1989. Disponível em: <http:// sf.oxfordjournals.org/content/68/2/531.short>. Acesso em: 22/4/2012. 
GRANJEIA, J. Escândalo da Fifa envolve J. Hawilla e contrato da CBF com empresa americana. O Globo, 27. maio 2015. Disponível em: $<$ https://oglobo.globo.com/esportes/escandalo-da-fifa-envolvehawilla-contrato-da-cbf-com-empresa-americana-16272765>.

GUIMARÃES, A.S. A bolsa-atleta eleva o desempenho de seus beneficiários? Análise do período 2005-2008 (Technical Report of Legislative Consulting in Brazilian National Congress). Brasilia: Senado Federal, 2009.

GUIMARÃES, C. CBF remonta bancada da bola em Brasília. LANCE!, 23. maio 2012. São Paulo. Disponível em: <http://blogs.lance.com.br/deprima/2012/05/23/ cbf-remonta-bancada-da-bola-em-brasilia/>.

HIRATA, E. A Mercantilização do Futebol e os subterrâneos da Legislação Esportiva Brasileira (1980-2010). In Anais do XXVI Simpósio Nacional de História - ANPUH. São Paulo: Associação Nacional de História (ANPUH), 2011, pp. 1-13.

INTINI, J. M.; FERNANDES, U. F. Bancada Ruralista: a face politica do agronegócio. Revista da ABRA, p. 70-86, 2013.

LEÃO JÚNIOR, F.P. de S. Corporativismo e conflitos na gestão do futebol brasileiro. Mediação, v. 5, n. 4, p. 31-51, 2004.

LOPES, N. A. A Frente Parlamentar Evangélica e sua atuação na Câmara dos Deputados, dez. 2013. Brasília - DF, Brasil: Universidade de Brasília (UnB). Disponível em: <http://bdm. unb.br/bitstream/10483/7140/1/2013_NoemiAraujoLopes.pdf $>$. Acesso em: 13/4/2016.

MACHADO, M. Doação ou investimento? : a atuação legislativa dos parlamentares da bancada ruralista e a questão do financiamento de campanhas, 2013. Brasilia: Universidade de Brasilia. Disponível em: <http://bdm.unb.br/handle/10483/7449>. MASQUIETTO, C. D.; SACOMANO NETO, M.; GIULIANI, A. C. Centralidade e Densidade em Redes de Empresas: um estudo no arranjo produtivo local do álcool. RAI - Revista de Administração e Inovação, v. 8, n. 1, p. 122-147, 2011.

MENDES, A. Política pública de esporte: considerações sobre gestão, instituições políticas e método de pesquisa no Brasil. Revista Intercontinental de Gestão Desportiva, v. 3, n. Suplemento 1, p. 1-19, 2013. Disponível em: <https://bit.ly/2MGRXsT> 
MENDES, A.; CODATO, A. Institutional System of the State and Public Policy: The Structure of Sports Management in Brazil. 14th Annual International Conference on Sports: Economic, Management, Marketing \& Social Aspects. Anais... p.1-37, 2014. Atenas: Athens Institute for Education and Research. Disponível em: <https://www.researchgate.net/publication/322048836_ Institutional_System_of_the_State_and_Public_Policy_The_ Structure_of_Sports_Management_in_Brazil $>$.

MESQUITA, R. B. DE; LANDIM, F. L. P.; COLLARES, P. M.; LUNA, C. G. DE. Análise de redes sociais informais: aplicação na realidade da escola inclusiva. Interface-Comunicação, Saúde, Educação, v. 12, n.26,p.549-562,2008.Disponívelem:<http://www.scielo.br/scielo. php? script $=$ sci_arttext $\&$ pid $=S 1414-32832008000300008 \& \operatorname{lng}=\mathrm{p}$ t\&tlng $=\mathrm{pt}>$

PERRONE, R. Deputado fala em receita anual de $\mathrm{R} \$ 1$ bi para clubes com lei polêmica. UOL Esporte, 22. nov. 2013. São Paulo. Disponível em: <https://blogdoperrone.blogosfera.uol. com.br/2013/11/deputado-fala-em-receita-anual-de-r-1-bi-paraclubes-com-lei-polemica/>.

REBELLO, A.; CRUZ, J. "Bancada da Bola” faz pressão e tira CBF de projeto sobre dívida dos times. UOL Esporte, 29. abr. 2014. São Paulo. Disponível em: <https://esporte.uol.com.br/futebol/ ultimas-noticias/2014/04/29/bancada-da-bola-faz-pressao-etira-cbf-de-projeto-sobre-divida-dos-times.htm $>$.

RelatordaMPdoFutebol(OtávioLeitedoPSDB/RJ)comenta escândalo envolvendo FIFA e CBF. ., 29. maio 2015. Brasil: TV Câmara. Disponível em: <https://www2.camara.leg.br/camaranoticias/tv/ materias/PALAVRA-ABERTA/489129-RELATOR-DA-MP-DOFUTEBOL-COMENTA-ESCANDALO-ENVOLVENDO-FIFAE-CBF.html>. Acesso em: 21/5/2016.

RIBEIRO, H.C.M. \& CORRÊA, R.,. Redes Sociais: um estudo em uma instituição de ensino superior privado. Revista Metropolitana de Sustentabilidade, vol. 3, n. 2, p.110-128, 2013.

SENA, V. P. Frentes parlamentares proliferam no Legislativo Federal. Departamento Intersindical de Assessoria Parlamentar, 4. jun. 2007. Brasília. Disponível em: <http://www.diap.org.br/index. php/noticias/artigos/5464-frentes-parlamentares-proliferam-nolegislativo-federal $>$. 
SILVA JR., J. A. DA; FIGUEIREDO FILHO, D. B.; PARANHOS, R.; ROCHA, E. C. DA. Quem controla o Legislativo? A ocupação de cargos de comando na Câmara dos Deputados. Paraná Eleitoral, v. 2, n. 2, p. 283-308, 2013. Curitiba.

SILVA, R. S. E; ARAÚJO, S. M. V. G. DE. Representações políticas alternativas no Congresso Nacional: uma proposta conceitual para compreender as Frentes Parlamentares. RDU, v. 16, n. 88, p. 232-256, 2019.

SILVA, T. M. DA. A bancada da bola no legislativo carioca: concepções, evidências e estratégias de uma representação singular, 2013. Fundação Getúlio Vargas. Disponível em: <http:// hdl.handle.net/10438/10689>.

STONE, L. Prosopography. Daedalus, v. 100, n. 1, p. 46-79, 1971. Disponível em: <www.jstor.org/stable/20023990>.

TICHY, N. M.; TUSHMAN, M. L.; FOMBRUN, C. Social Network Analysis For Organizations. Academy of Management Review, v. 4, n. 4, p. 507-519, 1979.

TOMAÉL, M. I.; MARTELETO, R. M. Redes sociais: posições dos atores no fluxo da informação. Encontros Bibli: revista eletrônica de biblioteconomia e ciência da informação, v. 11, n. 1, p. 75-91, 2007. Disponível em: <http://www.periodicos.ufsc.br/index.php/ eb/article/view/342>.

VERONEZ, L.F.C., 2005. Quando o Estado joga a favor do privado: as políticas de esporte após a Constituição federal de 1988 (Doctoral Dissertation in Physical Education). Campinas: Universidade Estadual de Campinas.

VIGNA, E. Bancada Ruralista: um grupo de interesse. Argumento, n. 8, p. 1-52, 2001. Brasilia: Instituto de Estudos Socioeconômicos (INESC). Disponível em: <https://docplayer.com.br/35656203-Issnbancada-ruralista-um-grupo-de-interesse-edelcio-vigna.html $>$.

VIGNA, E. Bancada ruralista: o maior grupo de interesse no Congresso Nacional. Instituto de Estudos Socioeconômicos (INESC), v. Ano VII, n. 12, p. 1-16, 2007.

VOGEL, L.H. As frentes parlamentares e a cultura política em defesa dos direitos humanos (Technical Report of Legislative Consulting in Brazilian National Congress). Brasília: Câmara dos Deputados, 2005. 
WASSERMAN, S.; FAUST, K. Social Network Analysis. Methods and Applications. Cambridge: Cambridge University Press, 1994. WOLF, F. O comportamento dos deputados na Câmara Federal : uma abordagem de redes sociais. (Master Dissertation in Political Science). Brasília: Universidade de Brasilia, 2008.

ZURBRIGGEN, C. El institucionalismo centrado en los actores: Una perspectiva analítica en el estudio de las políticas públicas. Revista de Ciencia Política, v. 26, n. 1, p. 67-83, 2006."

\section{Abstract}

Parliamentary Fronts (PF) are supra party institutions in the Brazilian National Congress (BNC) that aim to exert political clout in policies regarding a specific subject. Although seldom studied, these institutions have proliferated, and their number peaked in the 54 ${ }^{\text {th }}$ legislature (20112015) with a tally of 210 . In this article, we analyse the effectiveness of the Mixed Parliamentary Front for Sports (FPE), which comprises 198 federal deputies (from 513) and 8 senators (from 81). As method we combined: prosopography of its members; network analysis formed by the decisionmaking arenas occupied by them at BNC; analysis of their political clout in the legislation for sport. Our results indicate a network mainly comprised of right-wing parties and professional politicians, which suggests a strong potential of political clout. Four theoretical constructs from their profile characteristics were correlated to the centrality within the network, which showed that political expertise and political specialization were crucial factors. We found 8 central members, reinforcing arguments from literature which proposed the existence of an operative nucleus within PF. In relation to the clout in the formulation of sport policy, the representatives belonging to the front were responsible for 94 (61\%) proposals of the total of 246 bills presented in the field of sports. Moreover, they are not effective in approving these propositions, although more effective than others PF. Nevertheless, this research gave us a better understanding of policy formulation in complex political arenas, inaugurating a method to study effectiveness and centrality of this kind of institution.

Keywords: Keywords: sport policy, parliamentary fronts, political influence, prosopography, network analysis. 


\section{Resumo}

Frentes Parlamentares (FP) são instituições suprapartidárias no Congresso Nacional (CN) que visam exercer influência política sobre políticas relativas a um assunto específico. Embora ainda pouco estudadas, as FP proliferaram e seu número atingiu o pico na 54a legislatura (2011-2015) com 210 Frentes. Neste artigo, analisamos a eficácia da Frente Parlamentar Mista do Esporte (FPE), que compreende 198 deputados federais (de 513) e 8 senadores (de 81). Como método, combinamos análise prosopográfica de seus membros, análise de rede formada pelas áreas de tomada de decisão, análise de sua influência política na legislação esportiva. Nossos resultados indicam uma rede composta principalmente por partidos de direita e políticos profissionais, o que sugere um forte potencial de influência política. Quatro constructos teóricos, a partir de suas características de perfil, foram correlacionados com a centralidade da rede, o que mostrou que o conhecimento e a especialização política eram fatores cruciais. Encontramos 8 membros centrais, reforçando argumentos da literatura que propunha a existência de um núcleo operatório dentro das FPs. Em relação à influência na formulação da política esportiva, os representantes pertencentes à FPE foram responsáveis por 94 (61\%) propostas do total de 246 projetos de lei apresentados no campo do esporte. Mas eles não foram eficazes na aprovação dessas proposições, embora tenham sido mais eficazes que outras FPs. Essa pesquisa propicia uma melhor compreensão da formulação de políticas em arenas políticas complexas, inaugurando um método para estudar a eficácia e a centralidade desse tipo de instituição.

Palavras-chave: política esportiva, frentes parlamentares, influência política, prosopografia, análise de redes.

Recebido em 22 de julho de 2019

Aprovado em 12 de agosto de 2019 


\section{ERRATA: The effectiveness of the}

parliamentary front on sport in the Brazilian National Congress between the World Cup and the Olympic Games

No artigo The effectiveness of the parliamentary front on sport in the Brazilian National Congress between the World Cup and the Olympic Games, com número de DOI: 10.1590/0103-335220192904, publicado no periódico Revista Brasileira de Ciência Política, n29:121-154, disponível em http://dx.doi.org/10.1590/0103-335220192904,

na página 121 (e no cabeçalho das demais páginas)

Onde se lia:

"Adriano Nervo Codato"

Leia-se:

"Adriano Codato"

na página 121

Onde se lia:

(Gould 1989; Burt; Ansell et al., 2016).

Leia-se:

(Gould 1989; Burt, 1995; Ansell et al., 2016).

na página 122, nota de rodapé 4

Onde se lia:

“(Carta Capital 2015; Globo 2015; Câmara dos Deputados 2015)” Leia-se:

“(Carta Capital 2015; Câmara dos Deputados 2015)”

na página 123

Onde se lia:

"...methodological nature of them made by Silveira \& Silva (2019) that sought to identify..." 


\section{Leia-se:}

"...methodological nature of them made by Silva \& Araújo (2019) that sought to identify...”

na página 125

\section{Onde se lia:}

"(Bueno, 2008:248; Paulo 2012; Cruz, 2014; Damato \& Resende 2014; Rebello \& Cruz, 2014; Silva, 2013; Sampaio, 2014)”

\section{Leia-se:}

"(Bueno, 2008:248; Cruz, 2014; Guimarães, 2014; Rebello \& Cruz, 2014; Silva, 2013)"

na página 134

\section{Onde se lia:}

"Coradini (2010) Coradini's finding (2010: p.249)"

\section{Leia-se:}

"Coradini's finding (2010: p.249)"

na página 138

\section{Onde se lia:}

"(Cruz, 2014; Damato \& Resende, 2014; Rebello; Sampaio, 2014)" Leia-se:

"(Cruz, 2014; Damato \& Resende, 2014; Guimarães, 2014; Rebello \& Cruz, 2014)”

na página 140, nota de rodapé 11

\section{Onde se lia:}

"...concerning deputies (see note 16)."

\section{Leia-se:}

“...concerning deputies."

na página 147

\section{Onde se lia:}

"(Bombig, 2014; Sampaio, 2014)"

Leia-se:

"(Bombig, 2001)"

na seção References (página 148 a 152) 


\section{Onde se lia:}

"ANSELL, C.; BICHIR, R.; ZHOU, S. Who Says Networks, Says Oligarchy? Oligarchies as "Rich Club" Networks. Connections, v. 35, n. 2, p. 20-32, 2016. Disponível em: <http://insna.org/connections/v35/v35_2_2.html>.

BALESTRIN, A.; VARGAS, L. M. A dimensão estratégica das redes horizontais de PMEs: teorizações e evidências. Revista de Administração Contemporânea, v. 8, n. spe, p. 203-227, 2004. Disponível em: <http://www.scielo.br/scielo.php?script=sci_arttext\&pid=S1415-65552004000500011\&lng=pt\&tlng=pt $>$. .

BOMBIG, J. A. CPI da CBF/Nike termina sem relatório. Folha de S.Paulo, 14. jun. 2001. São Paulo. Disponível em: $<$ https://www1. folha.uol.com.br/fsp/esporte/fk1406200137.htm>. .

BUENO, L. Políticas publicas do esporte no Brasil: razões para o predomínio do alto rendimento, 2008. São Paulo: Fundação Getúlio Vargas. Disponível em: <http://hdl.handle. net $/ 10438 / 2493 \% 0 A>$. .

CÂMARA DOS DEPUTAdos. Ato da Mesa $n^{\circ} 69$ de 10/11/2005. Brasília: Diário da Câmara dos Deputados - Suplemento - B, 2005.

CASCIONE, S. R. S. Institucionalização e influência das frentes parlamentares no Congresso brasileiro, 2018. Universidade de Brasília. Disponível em: <http://repositorio.unb.br/bitstream/10482/31903/1/2018_SilvioRicardoSilvaCascione.pdf $>$. .

CERVI, E. U. Análise de elites em perspectiva relacional: a operacionalização da análise de redes sociais (ARS). In: R. Perissinotto; A. Codato (Orgs.); Como estudar elites. p.95-118, 2015. Curitiba: Editora UFPR.

CODATO, A.; BOLOGNESI, B.; ROEDER, K. M. A nova direita brasileira: uma análise da dinâmica partidária e eleitoral do campo conservador. In: S. V. e Cruz; A. Kaysel; G. Codas (Orgs.); Direita, volver! : o retorno da direita e o ciclo político brasileiro. p.115143, 2015. São Paulo: Editora Fundação Perseu Abramo. 
CORADINI, O. L. Frentes parlamentares, representação de interesses e alinhamentos políticos. Revista de Sociologia e Politica, v. 18, n. 36, p. 241-256, 2010.

CRUZ, J. Quem é quem na "bancada da bola". Disponível em: $<$ https://josecruz.blogosfera.uol.com.br/2014/05/quem-e-quem-na-bancada-da-bola-2/>. .

DACOSTA, L. P. Instalações esportivas por estado. In: L. P. DaCOSTA (Org.); Atlas do Esporte no Brasil. p.5.27-5.29, 2006 . Rio de Janeiro.

DACOSTA, L. P. Clubes esportivos e recreativos. In: L. P. DaCOSTA (Org.); Atlas do Esporte no Brasil. p.6.7-6.12, $2006 \mathrm{~b}$. Rio de Janeiro.

DEPUTADOS, C. DOS. Diário da Câmara dos Deputados. Diário da Câmara dos Deputados, 2005.

Em sua maioria, Bancada da Bola é reprovada nas urnas. .O Estado de S. Paulo, 8. out. 2012. São Paulo. Disponível em: <https:// esportes.estadao.com.br/noticias/futebol,em-sua-maioria-bancada-da-bola-e-reprovada-nas-urnas,942507>. .

Entenda o escândalo da Fifa e da CBF. .Carta Capital, 27. maio 2015. São Paulo. Disponível em: <https://www.cartacapital.com.br/ sociedade/entenda-o-escandalo-da-fifa-e-da-cbf-4139/>. .

GOULD, R. V. Power and social structure in community elites. Social Forces, v. 68, n. 2, p. 531-552, 1989. Disponível em: $<$ http://sf.oxfordjournals.org/content/68/2/531.short $>$. Acesso em: 22/4/2012.

GRANJEIA, J. Escândalo da Fifa envolve J. Hawilla e contrato da CBF com empresa americana. O Globo, 27. maio 2015. Disponível em: <https://oglobo.globo.com/esportes/escandalo-da-fifa-envolve-hawilla-contrato-da-cbf-com-empresa-americana-16272765>. .

GUIMARÃES, C. CBF remonta bancada da bola em Brasília. LANCE !, 23. maio 2012. São Paulo. Disponível em: <http://blogs.lance.com.br/deprima/2012/05/23/ cbf-remonta-bancada-da-bola-em-brasilia/ $>$.

INTINI, J. M.; FERNANDES, U. F. Bancada Ruralista: a face politica do agronegócio. Revista da ABRA, p. 70-86, 2013. 
LOPES, N. A. A Frente Parlamentar Evangélica e sua atuação na Câmara dos Deputados, dez. 2013. Brasília - DF, Brasil: Universidade de Brasília (UnB). Disponível em: <http://bdm.unb.br/bitstream/10483/7140/1/2013_NoemiAraujoLopes.pdf $>$. Acesso em: $13 / 4 / 2016$.

MACHADO, M. Doação ou investimento? : a atuação legislativa dos parlamentares da bancada ruralista e a questão do financiamento de campanhas, 2013. Brasilia: Universidade de Brasilia. Disponível em: <http://bdm.unb.br/handle/10483/7449>. .

'Marin e Del Nero tinham que estar presos', diz Romário. .Exame, 9. jul. 2014. São Paulo. Disponível em: <https://exame.abril.com.br/ estilo-de-vida/marin-e-del-nero-tinham-que-estar-presos-diz-romario/>. .

MENDES, A. Política pública de esporte: considerações sobre gestão, instituições políticas e método de pesquisa no Brasil. Revista Intercontinental de Gestão Desportiva, v. 3, n. Suplemento 1, p. 1-19, 2013. Disponível em: <http://www.revista.universo.edu.br/ index.php?journal=gestaoesportiva\&page $=$ article\&op $=$ view $\&$ pa th\%5B $\% 5 \mathrm{D}=1067 \&$ path\%5B $\% 5 \mathrm{D}=781>$. .

MENDES, A.; CODATO, A. Institutional System of the State and Public Policy: The Structure of Sports Management in Brazil. 14th Annual International Conference on Sports: Economic, Management, Marketing \& Social Aspects. Anais... . p.1-37, 2014. Atenas: Athens Institute for Education and Research. Disponível em: <https://www.researchgate.net/publication/322048836_Institutional_System_of_the_State_and_Public_Policy_The_Structure_ of_Sports_Management_in_Brazil $>$. .

PERRONE, R. Deputado fala em receita anual de R\$ 1 bi para clubes com lei polêmica. UOL Esporte, 22. nov. 2013. São Paulo. Disponível em: <https://blogdoperrone.blogosfera.uol.com. br/2013/11/deputado-fala-em-receita-anual-de-r-1-bi-para-clubes-com-lei-polemica/>. .

REBELLO, A.; CRUZ, J. "Bancada da Bola" faz pressão e tira CBF de projeto sobre dívida dos times. UOL Esporte, 29. abr. 2014. São Paulo. Disponível em: <https://esporte.uol.com.br/futebol/ 
ultimas-noticias/2014/04/29/bancada-da-bola-faz-pressao-e-tira-cbf-de-projeto-sobre-divida-dos-times.htm>. .

Relator da MP do Futebol (Otávio Leite do PSDB/RJ) comenta escândalo envolvendo FIFA e CBF. ., 29. maio 2015. Brasil: TV Câmara. Disponível em: <https://www2.camara.leg.br/camaranoticias/tv/materias/PALAVRA-ABERTA/489129-RELATOR-DA-MP-DO-FUTEBOL-COMENTA-ESCANDALO-ENVOLVENDO-FIFA-E-CBF.html>. Acesso em: 21/5/2016.

SENA, V. P. Frentes parlamentares proliferam no Legislativo Federal. Departamento Intersindical de Assessoria Parlamentar, 4. jun. 2007. Brasília. Disponível em: <http://www.diap.org.br/ index.php/noticias/artigos/5464-frentes-parlamentares-proliferam-no-legislativo-federal>. .

SILVA JR., J. A. DA; FIGUEIREDO FILHO, D. B.; PARANHOS, R.; ROCHA, E. C. DA. Quem controla o Legislativo? A ocupação de cargos de comando na Câmara dos Deputados. Paraná Eleitoral, v. 2, n. 2, p. 283-308, 2013. Curitiba.

SILVA, R. S. E; ARAÚJO, S. M. V. G. DE. Representações políticas alternativas no Congresso Nacional: uma proposta conceitual para compreender as Frentes Parlamentares. RDU, v. 16, n. 88, p. 232-256, 2019.

SILVA, T. M. DA. A bancada da bola no legislativo carioca: concepções, evidências e estratégias de uma representação singular, 2013. Fundação Getúlio Vargas. Disponível em: <http:// hdl.handle.net/10438/10689>.

STONE, L. Prosopography. Daedalus, v. 100, n. 1, p. 46-79, 1971. Disponível em: <www.jstor.org/stable/20023990>.

VIGNA, E. Bancada Ruralista: um grupo de interesse. Argumento, , n. 8, p. 1-52, 2001. Brasilia: Instituto de Estudos Socioeconômicos (INESC). Disponível em: <https://docplayer.com. br/35656203-Issn-bancada-ruralista-um-grupo-de-interesse-edelcio-vigna.html>.

VIGNA, E. Bancada ruralista : o maior grupo de interesse no Congresso Nacional. Instituto de Estudos Socioeconômicos (INESC), v. Ano VII, n. 12, p. 1-16, 2007. 
WASSERMAN, S.; FAUST, K. Social Network Analysis. Methods and Applications. Cambridge: Cambridge University Press, 1994.

\section{Leia-se agora :}

"ANSELL, C.; BICHIR, R.; ZHOU, S. Who Says Networks, Says Oligarchy? Oligarchies as "Rich Club" Networks. Connections, v. 35, n. 2, p. 20-32, 2016. Disponível em: <http://insna.org/connections/v35/v35_2_2.html>.

BALESTRIN, A.; VARGAS, L. M. A dimensão estratégica das redes horizontais de PMEs: teorizações e evidências. Revista de Administração Contemporânea, v. 8, n. spe, p. 203-227, 2004. Disponível em: <http://www.scielo.br/scielo.php?script=sci_arttext\&pid $=$ S1415-65552004000500011\&lng $=p t \& t \operatorname{lng}=p t>$.

BOMBIG, J. A. CPI da CBF/Nike termina sem relatório. Folha de S.Paulo, 14. jun. 2001. São Paulo. Disponível em: <https://www1. folha.uol.com.br/fsp/esporte/fk1406200137.htm > .

BUENO, L. Políticas publicas do esporte no Brasil: razões para o predomínio do alto rendimento, 2008. São Paulo: Fundação Getúlio Vargas. Disponível em: <http://hdl.handle. net $/ 10438 / 2493 \% 0$ A>.

BURT, R.S. Structural holes: the social structure of competition. Cambridge: Harvard University Press, 1995.

CÂMARA DOS DEPUTADOS. Ato da Mesa $n^{0} 69$ de 10/11/2005. Brasília: Diário da Câmara dos Deputados - Suplemento - B, 2005.

CÂMARA DOS DEPUTADOS Comissão Parlamentar de Inquérito destinada a apurar a regularidade do contrato celebrado entre a CBF e a Nike. 2001. Available at: http://www2.camara.leg.br/ atividade-legislativa/comissoes/comissoes-temporarias/parlamentar-de-inquerito/51-legislatura/cpinike/informacoes-sobre-a-cpi. Accessed at: 02 january 2016.

CÂMARA DOS DEPUTADOS, 2005b. Diário da Câmara dos Deputados, Year LX, Issue 197, p.237

CASCIONE, S. R. S. Institucionalização e influência das frentes parlamentares no Congresso brasileiro, 2018. Universidade 
de Brasília. Disponível em: <http://repositorio.unb.br/bitstream/10482/31903/1/2018_SilvioRicardoSilvaCascione.pdf $>$. .

CERVI, E. U. Análise de elites em perspectiva relacional: a operacionalização da análise de redes sociais (ARS). In: R. Perissinotto; A. Codato (Orgs.); Como estudar elites. p.95-118, 2015. Curitiba: Editora UFPR.

CHASERANT, C. Cooperation, contracts and social networks: From a bounded to a procedural rationality approach. Journal of Management and Governance, v. 7, n. 2, p. 163-186, 2003

CODATO, A.; BOLOGNESI, B.; ROEDER, K. M. A nova direita brasileira: uma análise da dinâmica partidária e eleitoral do campo conservador. In: S. V. e Cruz; A. Kaysel; G. Codas (Orgs.); Direita, volver! : o retorno da direita e o ciclo político brasileiro. p.115143, 2015. São Paulo: Editora Fundação Perseu Abramo.

CORADINI, O. L. Frentes parlamentares, representação de interesses e alinhamentos políticos. Revista de Sociologia e Politica, v. 18, n. 36, p. 241-256, 2010.

CRUZ, J. Quem é quem na "bancada da bola". Disponível em: $<$ https://josecruz.blogosfera.uol.com.br/2014/05/quem-e-quem-na-bancada-da-bola-2/> .

DACOSTA, L. P. Instalações esportivas por estado. In: L. P. DaCOSTA (Org.); Atlas do Esporte no Brasil. p.5.27-5.29, 2006a. Rio de Janeiro.

DACOSTA, L. P. Clubes esportivos e recreativos. In: L. P. DaCOSTA (Org.); Atlas do Esporte no Brasil. p.6.7-6.12, 2006 b. Rio de Janeiro.

Em sua maioria, Bancada da Bola é reprovada nas urnas. .O Estado de S. Paulo, 8. out. 2012. São Paulo. Disponível em: <https:// esportes.estadao.com.br/noticias/futebol,em-sua-maioria-bancada-da-bola-e-reprovada-nas-urnas,942507>. .

Entenda o escândalo da Fifa e da CBF. .Carta Capital, 27. maio 2015. São Paulo. Disponível em: <https://www.cartacapital.com.br/ sociedade/entenda-o-escandalo-da-fifa-e-da-cbf-4139/>. .

GOULD, R. V. Power and social structure in community elites. Social Forces, v. 68, n. 2, p. 531-552, 1989. Disponível em: 
$<$ http://sf.oxfordjournals.org/content/68/2/531.short $>$. Acesso em: 22/4/2012.

GRANJEIA, J. Escândalo da Fifa envolve J. Hawilla e contrato da CBF com empresa americana. O Globo, 27. maio 2015. Disponível em: <https://oglobo.globo.com/esportes/escandalo-da-fifa-envolve-hawilla-contrato-da-cbf-com-empresa-americana-16272765>. .

GUIMARÃES, A.S. A bolsa-atleta eleva o desempenho de seus beneficiários? Análise do período 2005-2008 (Technical Report of Legislative Consulting in Brazilian National Congress). Brasilia: Senado Federal, 2009.

GUIMARÃES, C. CBF remonta bancada da bola em Brasília. LANCE !, 23. maio 2012. São Paulo. Disponível em: <http://blogs. lance.com.br/deprima/2012/05/23/cbf-remonta-bancada-da-bola-em-brasilia/>. .

HIRATA, E. A Mercantilização do Futebol e os subterrâneos da Legislação Esportiva Brasileira (1980-2010). In Anais do XXVI Simpósio Nacional de História - ANPUH. São Paulo: Associação Nacional de História (ANPUH), 2011, pp. 1-13.

INTINI, J. M.; FERNANDES, U. F. Bancada Ruralista: a face politica do agronegócio. Revista da ABRA, p. 70-86, 2013.

LEÃO JÚNIOR, F.P. de S. Corporativismo e conflitos na gestão do futebol brasileiro. Mediação, v. 5, n. 4, p. 31-51, 2004

LOPES, N. A. A Frente Parlamentar Evangélica e sua atuação na Câmara dos Deputados, dez. 2013. Brasília - DF, Brasil: Universidade de Brasília (UnB). Disponível em: <http://bdm.unb.br/bitstream/10483/7140/1/2013_NoemiAraujoLopes.pdf $>$. Acesso em: $13 / 4 / 2016$.

MACHADO, M. Doação ou investimento? : a atuação legislativa dos parlamentares da bancada ruralista e a questão do financiamento de campanhas, 2013. Brasilia: Universidade de Brasilia. Disponível em: <http://bdm.unb.br/handle/10483/7449>.

MASQUIETTO, C. D.; SACOMANO NETO, M.; GIULIANI, A. C. Centralidade e Densidade em Redes de Empresas: um estudo no arranjo produtivo local do álcool. RAI - Revista de Administração e Inovação, v. 8, n. 1, p. 122-147, 2011. 
MENDES, A. Política pública de esporte: considerações sobre gestão, instituições políticas e método de pesquisa no Brasil. Revista Intercontinental de Gestão Desportiva, v. 3, n. Suplemento 1, p. 1-19, 2013. Disponível em: <http://www.revista.universo.edu.br/ index.php?journal=gestaoesportiva\&page $=$ article $\&$ op $=$ view\&path\%5B $\% 5 \mathrm{D}=1067 \&$ path $\% 5 \mathrm{~B} \% 5 \mathrm{D}=781>$. .

MENDES, A.; CODATO, A. Institutional System of the State and Public Policy: The Structure of Sports Management in Brazil. 14th Annual International Conference on Sports: Economic, Management, Marketing \& Social Aspects. Anais... . p.1-37, 2014. Atenas: Athens Institute for Education and Research. Disponível em: <https://www.researchgate.net/publication/322048836_Institutional_System_of_the_State_and_Public_Policy_The_Structure_ of_Sports_Management_in_Brazil>. .

MESQUITA, R. B. DE; LANDIM, F. L. P.; COLlARES, P. M.; LUNA, C. G. DE. Análise de redes sociais informais: aplicação na realidade da escola inclusiva. Interface - Comunicação, Saúde, Educação, v. 12, n. 26, p. 549-562, 2008. Disponível em: $<$ http://www.scielo.br/scielo.php?script=sci_arttext\&pid=S1414-32832008000300008\&lng=pt\&tlng=pt $>$

PERRONE, R. Deputado fala em receita anual de R 1 bi para clubes com lei polêmica. UOL Esporte, 22. nov. 2013. São Paulo. Disponível em: <https://blogdoperrone.blogosfera.uol.com. br/2013/11/deputado-fala-em-receita-anual-de-r-1-bi-para-clubes-com-lei-polemica/>. .

REBELLO, A. \& CRUZ, J., 2014. "Bancada da Bola” faz pressão e tira CBF de projeto sobre dívida dos times. Coluna UOL Esporte Futebol. Available at: http://esporte.uol.com.br/futebol/ultimas-noticias/2014/04/29/bancada-da-bola-faz-pressao-e-tira-cbf-de-projeto-sobre-divida-dos-times.htm. Accessed at: 02 january 2016. .

Relator da MP do Futebol (Otávio Leite do PSDB/ RJ) comenta escândalo envolvendo FIFA e CBF. ., 29. maio 2015. Brasil: TV Câmara. Disponível em: <https:// www2.camara.leg.br/camaranoticias/tv/materias/ 
PALAVRA-ABERTA/489129-RELATOR-DA-MP-DO-FUTEBOL-COMENTA-ESCANDALO-ENVOLVENDO-FIFA-E-CBF.html>. Acesso em: 21/5/2016.

RIBEIRO, H.C.M. \& CORRÊA, R.,. Redes Sociais: um estudo em uma instituição de ensino superior privado. Revista Metropolitana de Sustentabilidade, vol. 3, n. 2, p.110-128, 2013.

SENA, V. P. Frentes parlamentares proliferam no Legislativo Federal. Departamento Intersindical de Assessoria Parlamentar, 4. jun. 2007. Brasília. Disponível em: <http://www.diap.org.br/ index.php/noticias/artigos/5464-frentes-parlamentares-proliferam-no-legislativo-federal $>$. .

SILVA JR., J. A. DA; FIGUEIREDO FILHO, D. B.; PARANHOS, R.; ROCHA, E. C. DA. Quem controla o Legislativo? A ocupação de cargos de comando na Câmara dos Deputados. Paraná Eleitoral, v. 2, n. 2, p. 283-308, 2013. Curitiba.

SILVA, R. S. E; ARAÚJO, S. M. V. G. DE. Representações políticas alternativas no Congresso Nacional: uma proposta conceitual para compreender as Frentes Parlamentares. RDU, v. 16, n. 88, p. 232-256, 2019.

SILVA, T. M. DA. A bancada da bola no legislativo carioca: concepções, evidências e estratégias de uma representação singular, 2013. Fundação Getúlio Vargas. Disponível em: <http:// hdl.handle.net/10438/10689>. .

STONE, L. Prosopography. Daedalus, v. 100, n. 1, p. 46-79, 1971. Disponível em: <www.jstor.org/stable/20023990>.

TICHY, N. M.; TUSHMAN, M. L.; FOMBRUN, C. Social Network Analysis For Organizations. Academy of Management Review, v. 4, n. 4, p. 507-519, 1979.

TOMAÉL, M. I.; MARTELETO, R. M. Redes sociais: posições dos atores no fluxo da informação. Encontros Bibli: revista eletrônica de biblioteconomia e ciência da informação, v. 11, n. 1, p. 75-91, 2007. Disponível em: <http://www.periodicos.ufsc.br/index. $\mathrm{php} / \mathrm{eb} /$ article/view/342>.

VERONEZ, L.F.C., 2005. Quando o Estado joga a favor do privado: as políticas de esporte após a Constituição federal de 1988 
(Doctoral Dissertation in Physical Education). Campinas: Universidade Estadual de Campinas.

VIGNA, E. Bancada Ruralista: um grupo de interesse. Argumento, , n. 8, p. 1-52, 2001. Brasilia: Instituto de Estudos Socioeconômicos (INESC). Disponível em: <https://docplayer.com. br/35656203-Issn-bancada-ruralista-um-grupo-de-interesse-edelcio-vigna.html>. .

VIGNA, E. Bancada ruralista : o maior grupo de interesse no Congresso Nacional. Instituto de Estudos Socioeconômicos (INESC), v. Ano VII, n. 12, p. 1-16, 2007.

VOGEL, L.H. As frentes parlamentares e a cultura política em defesa dos direitos humanos (Technical Report of Legislative Consulting in Brazilian National Congress). Brasília: Câmara dos Deputados, 2005.

WASSERMAN, S.; FAUST, K. Social Network Analysis. Methods and Applications. Cambridge: Cambridge University Press, 1994.

WOLF, F. O comportamento dos deputados na Câmara Federal : uma abordagem de redes sociais. (Master Dissertation in Political Science). Brasília: Universidade de Brasilia, 2008.

ZURBRIGGEN, C. El institucionalismo centrado en los actores: Una perspectiva analítica en el estudio de las políticas públicas. Revista de Ciencia Política, v. 26, n. 1, p. 67-83, 2006."

na página 153 (Abstract)

Onde se lia:

"...inaugurating a method and a theory to study effectiveness and centrality of this kind of institution"

\section{Leia-se:}

"inaugurating a method to study effectiveness and centrality of this kind of institution"

na página 153 (Keywords)

\section{Onde se lia:}

"Keywords: sport policy, political institutions, political clout, prosopography, factorial analysis, network analysis." 


\section{Leia-se:}

"Keywords: sport policy, parliamentary fronts, political influence, prosopography, network analysis."

\section{na página 154 incluir as seções Resumo e Palavras-chave}

\section{Resumo}

Frentes Parlamentares (FP) são instituições suprapartidárias no Congresso Nacional (CN) que visam exercer influência política sobre políticas relativas a um assunto específico. Embora ainda pouco estudadas, as FP proliferaram e seu número atingiu o pico na 54 a legislatura (2011-2015) com 210 Frentes. Neste artigo, analisamos a eficácia da Frente Parlamentar Mista do Esporte (FPE), que compreende 198 deputados federais (de 513) e 8 senadores (de 81 ). Como método, combinamos análise prosopográfica de seus membros, análise de rede formada pelas áreas de tomada de decisão, análise de sua influência política na legislação esportiva. Nossos resultados indicam uma rede composta principalmente por partidos de direita e políticos profissionais, o que sugere um forte potencial de influência política. Quatro constructos teóricos, a partir de suas características de perfil, foram correlacionados com a centralidade da rede, o que mostrou que o conhecimento e a especialização política eram fatores cruciais. Encontramos 8 membros centrais, reforçando argumentos da literatura que propunha a existência de um núcleo operatório dentro das FPs. Em relação à influência na formulação da política esportiva, os representantes pertencentes à FPE foram responsáveis por 94 (61\%) propostas do total de 246 projetos de lei apresentados no campo do esporte. Mas eles não foram eficazes na aprovação dessas proposições, embora tenham sido mais eficazes que outras FPs. Essa pesquisa propicia uma melhor compreensão da formulação de políticas em arenas políticas complexas, inaugurando um método para estudar a eficácia e a centralidade desse tipo de instituição.

Palavras-chave: política esportiva, frentes parlamentares, influência política, prosopografia, análise de redes. 